\title{
Hypoxic resistance of KRAS mutant tumor cells to 3-Bromopyruvate is counteracted by Prima- 1 and reversed by $\mathrm{N}$ - acetylcysteine
}

\author{
Andrea Orue, Valery Chavez, Mary Strasberg-Rieber and Manuel Rieber ${ }^{*}$
}

\begin{abstract}
Background: The metabolic inhibitor 3-bromopyruvate (3-BrPA) is a promising anti-cancer alkylating agent, shown to inhibit growth of some colorectal carcinoma with KRAS mutation. Recently, we demonstrated increased resistance to 3-BrPA in wt p53 tumor cells compared to those with p53 silencing or mutation. Since hypoxic microenvironments select for tumor cells with diminished therapeutic response, we investigated whether hypoxia unequally increases resistance to 3-BrPA in wt p53 MelJuso melanoma harbouring (Q61L)-mutant NRAS and wt BRAF, C8161 melanoma with (G12D)-mutant KRAS (G464E)-mutant BRAF, and A549 lung carcinoma with a KRAS (G12S)-mutation. Since hypoxia increases the toxicity of the p53 activator, Prima-1 against breast cancer cells irrespective of their p53 status, we also investigated whether Prima-1 reversed hypoxic resistance to 3-BrPA.

Results: In contrast to the high susceptibility of hypoxic mutant NRAS MelJuso cells to 3-BrPA or Prima-1, KRAS mutant C8161 and A549 cells revealed hypoxic resistance to 3-BrPA counteracted by Prima-1. In A549 cells, Prima-1 increased p21CDKN1mRNA, and reciprocally inhibited mRNA expression of the SLC2A1-GLUT1 glucose transporter-1 and ALDH1A1, gene linked to detoxification and stem cell properties. 3-BrPA lowered CAIX and VEGF mRNA expression. Death from joint Prima-1 and 3-BrPA treatment in KRAS mutant A549 and C8161 cells seemed mediated by potentiating oxidative stress, since it was antagonized by the anti-oxidant and glutathione precursor $\mathrm{N}$-acetylcysteine.
\end{abstract}

Conclusions: This report is the first to show that Prima-1 kills hypoxic wt p53 KRAS-mutant cells resistant to 3-BrPA, partly by decreasing GLUT-1 expression and exacerbating pro-oxidant stress.

Keywords: Hypoxia, ALDH1A1, GLUT1, p53 reactivation, KRAS mutation

\section{Background}

Tumor progression includes clonal selection of cells with mutated RAS or an inactive p53 tumor suppressor gene, leading to increased survival within the hypoxic tumor microenvironment. Aberrant signaling pathways induced by oncogenic KRAS mutations may help inactivate the functionality of the p53 tumor suppressor gene through critical effectors of oncogenic KRAS like Snail [1], Notch1 [2] or Ral GTPases [3]. Down-regulation of KRAS, RalB,

\footnotetext{
* Correspondence: manuel.rieber@gmail.com

IVIC, Tumor Cell Biology Laboratory, Apartado 21827, Caracas 1020A, Venezuela
}

(c) The Author(s). 2016 Open Access This article is distributed under the terms of the Creative Commons Attribution 4.0 International License (http://creativecommons.org/licenses/by/4.0/), which permits unrestricted use, distribution, and reproduction in any medium, provided you give appropriate credit to the original author(s) and the source, provide a link to the Creative Commons license, and indicate if changes were made. The Creative Commons Public Domain Dedication waiver (http://creativecommons.org/publicdomain/zero/1.0/) applies to the data made available in this article, unless otherwise stated. dependent up-regulation of the expression of p21CDKN1A [3]. Prima-1 (2,2-bis(hydroxymethyl)-1-azabicyclooctan-3one) like Prima-1 Met/APR-246, belongs to a group of nongenotoxic small molecules that promote mutant p53 reactivation and significant growth inhibition in several human tumor cells [4-9]. More recently, these drugs were reported to activate wild-type p53 and induce apoptosis in wt p53 malignant melanoma tumors [7], and in hypoxic wt p53 breast cancer cells [8]. Prima- $1^{\text {Met }}$ also has been shown to induce apoptosis in multiple myeloma [9], Ewing sarcoma irrespective of p53 status [10], in human prostate 
cancer, in a mouse leukemia cell line lacking p53 expression [11] and even in tumor cells lacking p53 through inhibition of thioredoxin reductase I [12]. A common mechanism to explain the loose dependence on p53 in the response to Prima- 1 or Prima- $1^{\text {Met }}$ could be that they take advantage of the high levels of oxidative stress common to tumor cells harbouring mutant p53 [8, 13] or oncogenic KRAS [14]. Supporting a role of oxidative stress in p53 reactivation, normoxic wt p53 breast cancer cells [8] and multiple myelomas [9] increase their susceptibility to Prima-1 with agents that impair the GSH/ROS balance like the glutathione antagonist, buthionine sulfoximine, which antagonizes cellular anti-oxidant defence $[8,9]$. Reactive oxygen species (ROS) are also a byproduct of metabolism, being produced during electron transfer by high metabolic consumption in tumor cells with moderate ROS levels driving metabolic processes but high ROS promoting cell death [13, 14]. Oncogenic KRAS mutations increase ROS levels [14] and overexpression of GLUT1 in lung carcinomas [15]. This glucose receptor 1 (SLC2A1-GLUT1) transports glucose which has a role in antioxidant defense [16], since it is the first substrate in the pentose phosphate pathway generating $\mathrm{NADPH}$, capable of donating electrons to antioxidant pathways to attenuate excessive oxidative stress [14-16]. Agents having anti-oxidant properties like pyruvate or Nacetylcysteine also counteract death by glucose depletion in human tumor cells [17]. Detoxification of stress caused by reactive lipid peroxidation can be helped by ALDH1A1 (EC 1.2.1.36) a putative cancer stem cell marker [18] belonging to a superfamily of $\mathrm{NAD}(\mathrm{P})^{+}$-dependent enzymes that catalyze the oxidation of a wide variety of endogenous and exogenous aldehydes to their corresponding carboxylic acids $[18,19]$. ALDH1A1 has prognostic significance in non-small cell lung cancer [19]. In tumor progression, cancer cells adapt to hypoxic stress by inducing expression of genes coding for carbonic anhydrase IX (CAIX) [20-22] or vascular endothelial growth factor (VEGF) [23], which also are important targets in cancer therapy. As a redox-active transcription factor, the p53 protein core DNA-binding domain when in contact with DNA, can sense oxidative stress. When cells are exposed to Prima-1 or to Prima1(MET), these molecules yield several active products among them methylene quinuclidinone (MQ), that reacts covalently to alkylate p53 cysteine residues and reactivate p53 function [6]. Moreover, MQ can also target cells irrespective of $\mathrm{p} 53$ by inhibiting thioredoxin reductase I and converting it to a pro-oxidant NADPH oxidase to further increase oxidative stress $[6,12]$. Another potent prooxidant is 3-bromopyruvate (3-BrPA), a metabolic competitor of pyruvate [17], and an alkylating agent capable of depleting ATP and increasing metabolic stress by generating free radicals $[24,25]$. 3-BrPA preferentially suppressed the growth of some colorectal carcinoma cells with KRAS or BRAF mutations which survived glucose starvation [26].
Since hypoxia [8] and some RAS mutations [26] may increase drug resistance partly by favouring p53 tumor suppressor dysfunction [8], this report investigated whether hypoxia unequally induces resistance to 3-BrPA in wt p53 tumor cells like MelJuso melanoma harbouring (Q61L)mutant NRAS and wt BRAF, C8161 melanoma with (G12D)-mutant KRAS (G464E)-mutant BRAF and A549 lung carcinoma with a KRAS (G12S)-mutation. We also investigated whether the p53 reactivator, Prima-1 counteracts a possible hypoxic resistance to 3-BrPA. The rationale for studying Prima-1, which alkylates critical p53 thiol groups $[6,27]$ together with 3-BrPA, which alkylates key thiol groups in glycolytic and mitochondrial targets $[24,25]$, is because of their possible synergism to increase $\operatorname{ROS}[25,26]$ and prevent proliferation and expression of genes associated with hypoxia and/or glycolysis in cells harbouring mutant RAS and a wt p53 gene.

\section{Methods \\ Cell Lines \\ Human melanoma cells}

a) MelJuso cells are wt BRAF and mutated in NRASQ61L [28].

b) C8161 cells were initially reported to be wild-type for both N-RAS and BRAF (http://www.wistar.org/ lab/meenhard-herlyn-dvm-dsc/page/mapk-and-pi3kpathways) with greater resistance to MEK inhibition in three-dimensional culture [29]. Quite recently, these cells were identified as having a G464E mutation in the BRAF P loop region, accompanied by an enhancing KRAS G12D mutation [30].

\section{Non-small cell lung cancer cells}

c) The A549 human lung adenocarcinoma cell line (www.atcc.org/ /ps/CRM-CCL-185.ashx) is being used as an in vitro model for non-small cell lung cancer (NSCL) harbouring a wt p53 gene and a KRAS gene mutation (p.G12S c.34G > A). These wt p53 NSCL cells were found to be resistant to a $24 \mathrm{~h}$ treatment with $100 \mu \mathrm{M}$ Prima-1 under normoxia [31].

\section{Cell culture conditions and treatments under high glucose or physiological glucose}

Sparse cells were allowed to attach to tissue-culture dishes for $20 \mathrm{~h}$ in high serum- glucose medium consisting of Dulbecco's Modified Medium (DME) Sigma Cat \# D1152 containing $4.5 \mathrm{~g} / \mathrm{lL}$ glucose $(\sim 23 \mathrm{mM})$ supplemented with $4 \mathrm{mM}$ glutamine and $10 \%$ fetal calf serum. Treatments were added in this higher glucose medium for the indicated times. For studies in the low glucose medium, 
adherent cells seeded for $20 \mathrm{~h}$ in high serum- glucose medium were washed 3 times in isotonic phosphatebuffered saline pH 7.3, followed by addition of Dulbecco's Modified Eagle's Medium Sigma Cat \# D5030, $5 \mathrm{mM}$ physiological glucose, $2 \mathrm{mM}$ glutamine and $5 \%$ dialyzed calf serum, together with other conditions indicated in each experiment [17]. Water-soluble reagents like Prima1(Sigma \#P0069) and/or 3-BrPA (Sigma Aldrich \#238341) were freshly prepared [25], and added whenever indicated. Unequal time duration of experiments were chosen to harvest and analyze cells at different times, depending on whether earlier changes in RNA and protein, cell cycle events or overt cytotoxicity were studied.

\section{Hypoxia experiments}

These were carried out in a hypoxic C-474 chamber equipped with Pro-Ox 110 oxygen controlling regulators (Biospherix, New York, N.Y.) to provide ( $\leq 2 \%$ oxygen).

\section{Relative cell viability/metabolic activity}

This was estimated with Alamar Blue (resazurin) by measuring intracellular redox mitochondrial activity by quantitating the cell-catalyzed conversion of nonfluorescent resazurin to fluorescent resorufin [8]. Alamar Blue was added to a $10 \%$ final concentration to each one of 96 well plates after the appropriate treatment. This assay is valuable as an endpoint of proliferation or relative viability/metabolic activity. For these experiments, cells $(5,000)$ were allowed to adhere overnight in 96 well TC plates. After the corresponding treatments, Alamar Blue (BioSource, Camarillo, CA, USA) was added without removing medium containing dead cells, and fluorescence measured $4 \mathrm{~h}$ later in a Fluoroskan Ascent microplate reader with an excitation of $544 \mathrm{~nm}$ and an emission of $590 \mathrm{~nm}$. Standard deviations (S.D.) were used to determine a statistically significant difference in the octuplicate median values shown for metabolic activity/cell viability. Generally, S.D. results usually were within $\pm 5 \%$ with a $95 \%$ statistical significance $(n=4)$. The criterion for statistical significance was taken as $p<0.05$ by student $t$ test, whenever indicated by *.

\section{High content cell cycle analysis by fluorescent imaging}

This was carried out using the Cell Cycle BioApplication algorithm provided with the Cellomics Arrayscan VTI at a magnification of 10X, used to identify objects by nuclear staining with Hoechst dye. A minimum of 500 individual cellular images or 20 fields were captured for each condition. The algorithm measured total nuclear intensity and selected for below $2 \mathrm{n}$ (subG1 dead cells), 2n (G1 cells), 2n-4n (S phase cells), 4 n (G2 cells) and above 4n DNA (multiplody or hypertetraploid cells) [32]. Generally, S.D. results usually were within $\pm 5 \%$.

\section{Intracellular ROS Quantitation}

ROS intracellular generation was assayed in adherent A549 cells seeded in 96 well plates after $9 \mathrm{~h}$ of exposure to the indicated treatments in medium supplemented with $5 \mathrm{mM}$ glucose. This was quantitated adding DCFH-DA (Life Technologies), a cell permeable non-fluorescent compound that can be hydrolyzed by intracellular esterases to $\mathrm{DCFH}$, which fluoresces green when oxidized by $\mathrm{H}_{2} \mathrm{O}_{2}$. Cells were exposed for $30 \mathrm{~min}$ to $20 \mu \mathrm{M}$ DCFH-DA and $20 \mu \mathrm{M}$ LavaCell (Active Motif. Carlsbad, California 92008, USA) a cell-permeable, non-toxic compound that stains membranes of live cells orange-red emission (560-580 nM) for $30 \mathrm{~min}$. Cell-associated fluorescence was determined in octuplicates, using the signal thresholding algorithms to identify fluorescence above the solution background from which fluorescent cells are identified in an Isocyte argon laser spectrofluorometer (Blueshift Biotechnologies, Inc., Sunnyvale, Ca.) identifying ROS in channel 1 green fluorescence (510-540) normalized to channel 3 orange-red cell fluorescence $(560-580 \mathrm{~nm})$.

\section{Crystal violet staining of surviving cells}

Cells were subjected to the treatments indicated in each experiment. Surviving cells were evidenced following fixation in $90 \%$ ethanol and cell staining with $0.5 \%$ crystal violet (Cat \# C-3886, Sigma-Aldrich, St. Louis, MO. 63103, USA) in $30 \%$ ethanol.

\section{Real-time and end-point RT-PCR}

Cells were seeded in $5 \mathrm{~cm}$-well plates $\left(3 \times 10^{5}\right.$ cells per plate) in complete Dulbecco's medium containing $20 \mathrm{mM}$ glucose supplemented with $10 \%$ serum for $24 \mathrm{~h}$. Cells were washed $3 \mathrm{X}$ with PBS and treated as indicated in medium supplemented with physiological $5 \mathrm{mM}$ glucose and 5\% dialyzed serum for $24 \mathrm{~h}$. RNA extraction was performed using TRIZOL ${ }^{\bullet}$ (Life Technologies, Cat \# 15596-026) and quantification was determined using a Qubit $^{\circ}$ 2.0 Fluorometer (Life Technologies, Cat \#Q32866) with a Qubit ${ }^{\text {mi }}$ RNA Assay Kit (Life Technologies, Cat \# Q32852). The cDNA was prepared with the ProtoScript $^{\circ}$ First Strand cDNA Synthesis Kit (New England BioLabs, Cat \# E6300S) using oligo dT as a primer. A GeneAmp PCR System 9700 ABI machine was used for end-point PCR, followed by agarose gel electrophoresis, to confirm lack of reaction in the absence of template, and expected size of PCR products. All amplification reactions were prepared with $\mathrm{Q}^{\circ}$ HighFidelity PCR Kit (New England BioLabs, Cat \# E0555S). Real Time qPCR was carried out in an Illumina Eco Real-Time PCR machine, in reactions $(10 \mu \mathrm{L})$ containing $5 \mu \mathrm{L}$ KAPA SYBR FAST qPCR Master Mix (Kapa Biosystems), $0.5 \mu \mathrm{M}$ of each primer pair, $1 \mu \mathrm{L}$ of cDNA template 
Table 1 Primer sequence for SYBR Green RT-qPCR and end point PCR analysis

\begin{tabular}{|c|c|c|}
\hline Gen Name & Primer sequence Fw & Primer sequence Rv \\
\hline ACTN & 5'- CATGTACGTTGCTATCCAGGC-3' & 5'- CTCCTTAATGTCACGCACGAT-3' \\
\hline GAPDH & 5'- GCACCACCAACTGCTTAGCA-3' & 5'-TGGCAGTGATGGCATGGA-3' \\
\hline SLC2A1 -GLUT1 & 5'- CGGGCCAAGAGTGTGCTAAA-3' & 5'- TGACGATACCGGAGCCAATG-3'. \\
\hline CAIX & 5'- ATCCTAGCCCTGGTTTTTGG-3' & 5'- GCTCACACCCCCTTTGGTT-3' \\
\hline ALDH1A1 & 5'- CAAGATCCAGGGCCGTACAA-3' & 5'- CAGTGCAGGCCCTATCTTCC-3' \\
\hline LDHA & 5'- ATCTTGACCTACGTGGCTTGGA-3' & 5'- CCATACAGGCACACTGGAATCTC-3 \\
\hline p21 CDK1N1 & 5'- GGACCTGGAGACTCTCA-3' & 5'- CCTCCTGGAGAAGATCAG-3' \\
\hline
\end{tabular}

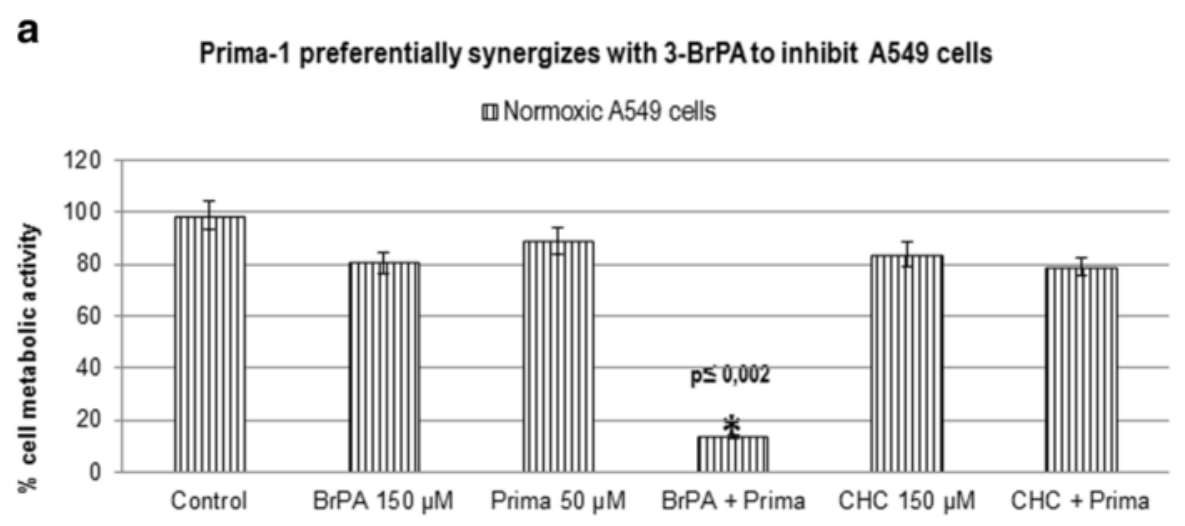

\section{b}

Prima-1 lowers GLUT1 expression

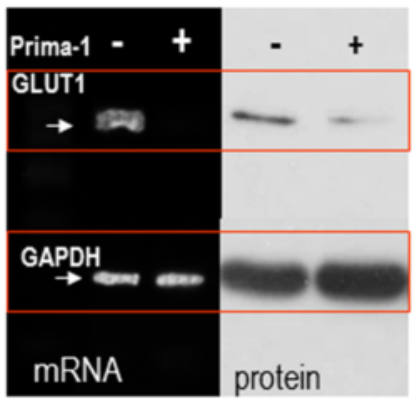

C

PRIMA-1 activates p21CDKN1A gene expression in A549 cells

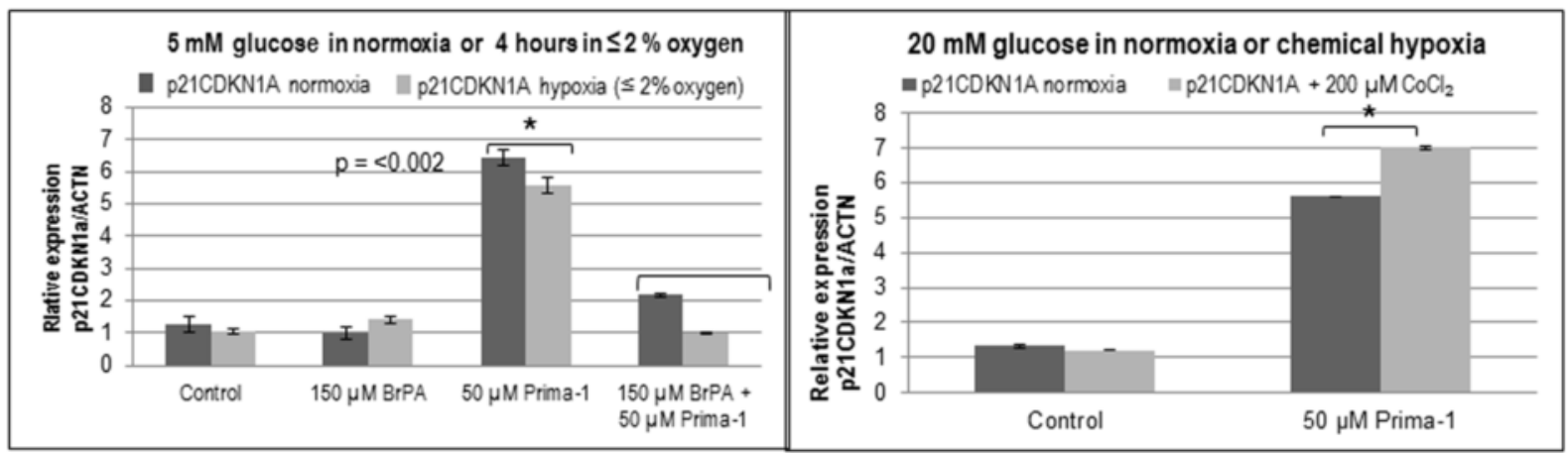

Fig. 1 a 3-BrPA potentiates Prima-1 toxicity against A549 cells in $5 \mathrm{mM}$ glucose. A549 cells (4X103) were seeded in tissue culture 96 well plates in complete medium containing $20 \mathrm{mM}$ glucose and 10\% fetal bovine serum, then washed $3 \mathrm{X}$ with PBS and treated as indicated in each case, in medium supplemented with physiological $5 \mathrm{mM}$ glucose, $2 \mathrm{mM}$ glutamine and $5 \%$ dialyzed serum for $48 \mathrm{~h}$. Relative proliferation /toxicity was assayed fluorometrically in octuplicate by the Alamar Blue method by quantitating the conversion of resazurin to fluorescent resorufin [8]. This revealed that $50 \mu \mathrm{M}$ Prima-1 cooperated with 3-BrPA rather than with CHC to suppress A549 cell growth. b Prima-1 decreases SLC2A1-GLUT1 in A549 cells. Sparse cells were seeded in $5 \mathrm{~cm}$ tissue culture plates $\left(5 \times 10^{5} \mathrm{cells}\right.$ per plate) in complete Dulbecco's medium containing $20 \mathrm{mM}$ glucose supplemented with $10 \%$ serum for $18 \mathrm{~h}$, then washed $3 \mathrm{X}$ with PBS and treated as indicated in each case, in medium supplemented with physiological $5 \mathrm{mM}$ glucose, $2 \mathrm{mM}$ glutamine and 5\% dialyzed serum whenever indicated (+) for $24 \mathrm{~h}$. After RNA extraction with TRIZOL and quantification in a Qubit ${ }^{\oplus}$ 2.0 Fluorometer, cDNAs were prepared for end-point PCR analysis as indicated under Methods.essentially similar results were obtained in cells treated with Prima-1 in $5 \mathrm{mM}$ glucose (not shown). Cells treated in parallel with those used for RNA analysis were used for GLUT1 protein immune blot [40]. c Prima-1 activates p21CDKN1A gene expression in A549 cells in $5 \mathrm{mM}$ glucose. qPCR was used to determine relative expression of the p21CDK1N1 gene in control and treated cells, after RNA extraction, CDNA preparation and qPCR, as indicated under Methods. *denotes significance between treated cells relative to controls 
(ng) and $1 \mu \mathrm{L}$ RNAse-DNAse free water. PCR reactions were subjected to $95{ }^{\circ} \mathrm{C}$ for $3 \mathrm{~min}$; followed by 40 cycles at $95{ }^{\circ} \mathrm{C}$ for $10 \mathrm{~s}$ and $60{ }^{\circ} \mathrm{C}$ for $30 \mathrm{~s}$. This was followed by melting curve analysis. The primers sequences used described in Table 1, were obtained from Integrated DNA Technologies (IDT, Coralville, IA 52241, USA). In all cases, the expression of each gene was normalized by measuring the expression of the similarly treated housekeeping gene coding for actin (ACTN) or for glyceraldehyde-3phosphate (GAPDH). All experiments were performed in triplicate. SigmaPlot 11.0 software was used for the statistics analysis of one-way analysis of variance or one-way ANOVA ( $p \leq 0.01$ or $p \leq 0.05$ significance).

\section{Immunofluorescence staining}

Immunofluorescence (IF) staining of cells was performed as previously described [33]. In brief, cells cultured on 96-well plates as indicated for each experiment, were washed with ice-cold PBS and fixed with $4 \%$ p-formaldehyde in phosphate-buffered saline. Cells were permeabilized with PBS containing $0.3 \%$ Triton X-100 and blocked in the same buffer adding $10 \mathrm{mg} / \mathrm{ml}$ bovine serum albumin and 1:1 dilution of mouse pre-immune serum. Subsequently, cells were incubated overnight with anti-human FITC-conjugated to GLUT1 monoclonal antibody MAB1418 clone 202915 diluted 1:8. and MAB 293 human VEGF mouse monoclonal antibody clone 26503, both from R\&D (614 McKinley Place N.E. Minneapolis, MN55413 USA) followed by a $90 \mathrm{~min}$ incubation with Alexa Fluor 488-conjugated anti-mouse secondary antibody (Invitrogen). Examination of green GLUT1 was carried out in separate assays by fluorescence microscopy in which DNA containing nuclei were stained violet with Hoechst 33342. Cells showed no fluorescence after reaction with a negative control IgG in contrast to the reactivity seen with the specific monoclonal antibodies used.

\section{Results}

Prima-1 lowers SLC2A1-GLUT1 mRNA and protein expression and cooperates with 3-BrPA to promote toxicity against normoxic A549 cells

Initially, we analyzed the cell proliferation of A549 cells cultured aerobically in complete medium with $10 \%$ fetal bovine serum and $20 \mathrm{mM}$ glucose. Previously, others reported that A549 cells resisted growth inhibition by $100 \mu \mathrm{M}$ Prima-1 under normoxic conditions [31]. Now, we observed a limited response of A549 cells to $50 \mu \mathrm{M}$ Prima-1

Prima-1 cooperates with 3-BrPA to increase ROS

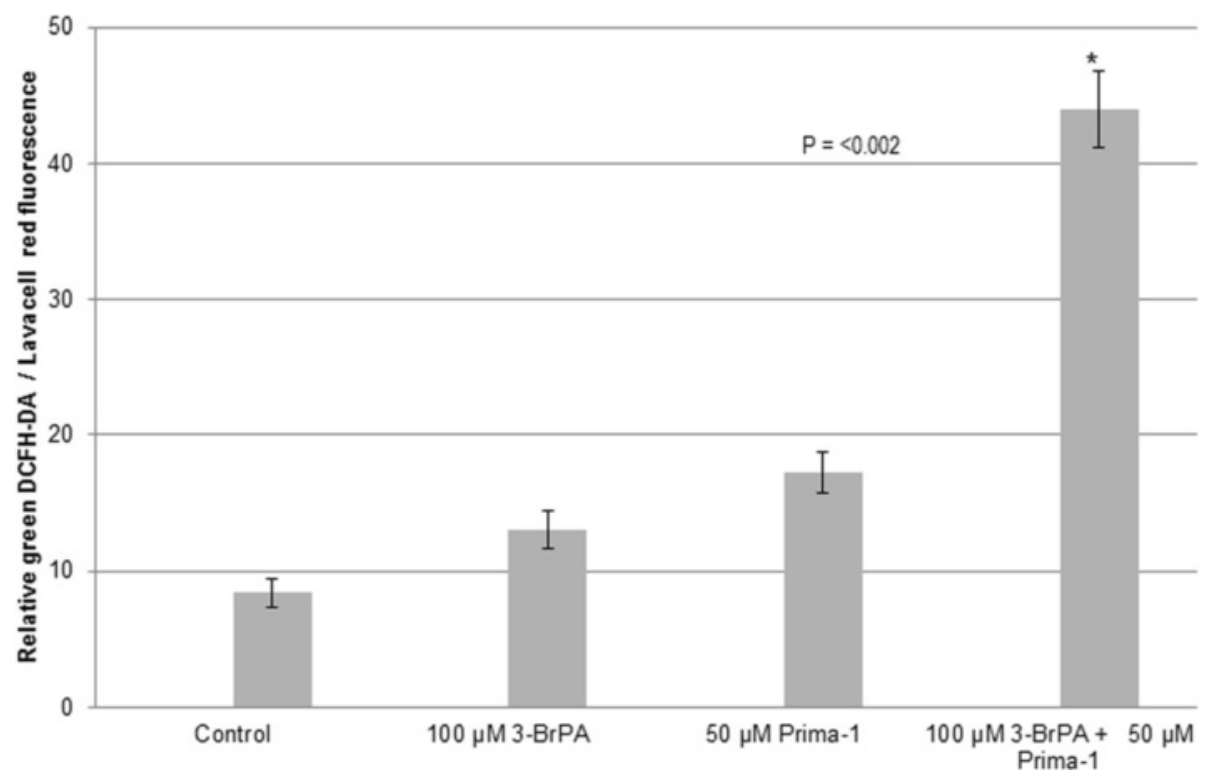

Fig. 2 Prima-1 and 3-BrPA cooperate to increase ROS. ROS intracellular generation was assayed in octuplicates in adherent A549 cells seeded in 96 well plates $10 \mathrm{~h}$ after exposure to the indicated treatments in medium supplemented with $5 \mathrm{mM}$ glucose, $2 \mathrm{mM}$ glutamine and 5\% dialyzed serum. This was quantitated using DCFH-DA (Life Technologies), a cell permeable non-fluorescent compound that can be hydrolyzed by intracellular esterases to DCFH, which fluoresces green when oxidized by $\mathrm{H}_{2} \mathrm{O}_{2}$. Cells were exposed to $20 \mu \mathrm{M}$ DCFH-DA together with 20 MM LavaCell (Active Motif. Carlsbad, California 92008, USA) for 30 min. The latter is also a cell-permeable, non-toxic compound that stains membranes of live cells providing an orange-red emission (560-580 nM). Cell-associated fluorescence was determined using the signal thresholding algorithms identify fluorescence above the solution background from which fluorescent cells are identified for calculation of morphological and fluorescent parameters in an Isocyte argon laser spectrofluorometer identifying channel 1 green fluorescence (510-540) normalized to channel 3 orange-red cell fluorescence $(560-580 \mathrm{~nm})$. *denotes significance between treated cells relative to controls 
or $150 \mu \mathrm{M} 3$-BrPA after $48 \mathrm{~h}$ treatments in physiological $5 \mathrm{mM}$ glucose [7]. However, both agents cooperated to suppress A549 cell proliferation. In contrast, $150 \mu \mathrm{M}$ of the monocarboxylate transporter inhibitor, alpha-cyano-4-hydroxy-cinnamate (CHC) [34] did not increase Prima-1 toxicity (Fig. 1a). End-point semi-quantitative PCR and western blot were carried out with cells treated for shorter intervals than those used for inhibition of cell proliferation, since early morphological changes were seen following Prima-1 treatment (not shown). These experiments revealed a marked inhibition of SLC2A1-GLUT1 mRNA and diminished GLUT1 protein expression normalized to GAPDH in A549 cells treated with $50 \mu \mathrm{M}$ Prima-1 (Fig. 1b). Essentially similar results were obtained in experiments in which cells were similarly treated but in the presence of $20 \mathrm{mM}$ glucose (not shown).
p21CDKN1A gene expression is increased by Prima-1 but not by 3-BrPA in A549 cells

Since Prima-1 is known to be a p53 reactivator $[3,6,7]$, and the cyclin-dependent kinase inhibitor p21CDKN1 is a p53-activated gene promoting the $\mathrm{G} 1$ checkpoint control $[35,36]$ we confirmed by qPCR that Prima-1 increased expression of the p21CDKN1A mRNA in $5 \mathrm{mM}$ or $20 \mathrm{mM}$ glucose in A549 cells. However, this was antagonized by concomitant treatment with 3-BrPA (Fig. 1c), known to induce cell cycle arrest in $\mathrm{S}$ phase and G2/M [37]. The reciprocal effects of Prima-1 and 3BrPA on p21CDKN1A expression may be related to the fact that they act at different cell cycle positions. It was of interest that the Prima-1 mediated increase in p21CDKN1A occurred in normoxia, hypoxia or in the presence of the hypoxia mimetic $\mathrm{CoCl}_{2}$ (Fig. 1d). a

$$
\begin{aligned}
& \text { NAC counteracts toxicity of Prima-1 } \pm \text { 3-BrPA } \\
& \text { in (G12S)-mutant KRAS-A549 cells }
\end{aligned}
$$

$20 \mathrm{mM}$ glucose $+4 \mathrm{mM}$ glutamine $+10 \%$ serum

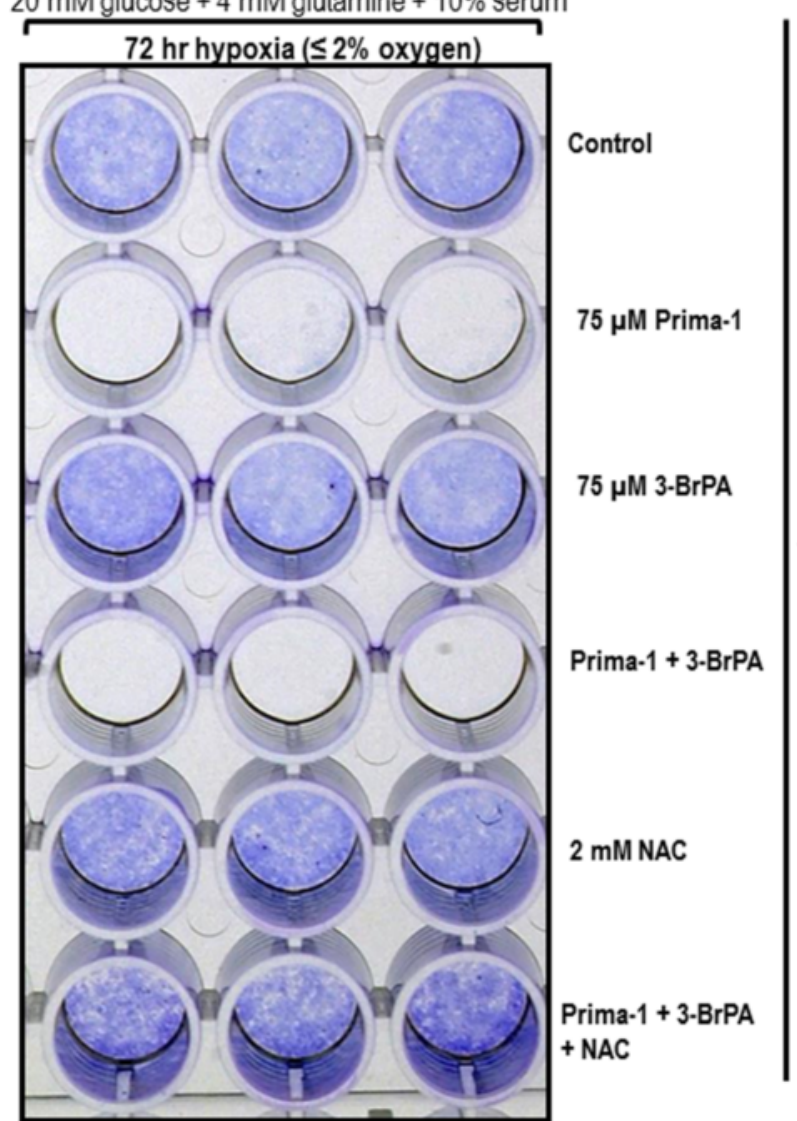

b

Prima-1 and 3-BrPA cooperate to inhibit cell cycle progression and promote $(<2 n)$ cell death antagonized by NAC

$20 \mathrm{mM}$ glucose $+4 \mathrm{mM}$ glutamine $+10 \%$ serum hypoxia ( $\leq 2 \%$ oxygen)

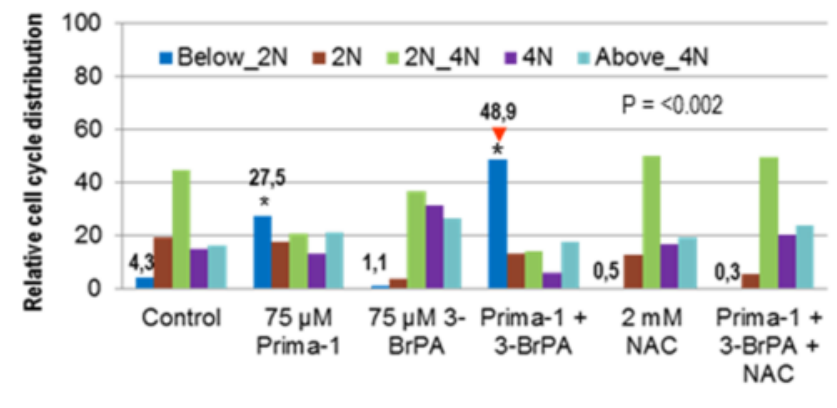

C

$5 \mathrm{mM}$ glucose $+2 \mathrm{mM}$ glutamine $+5 \%$ dialyzed serum hypoxia ( $\leq 2 \%$ oxygen)

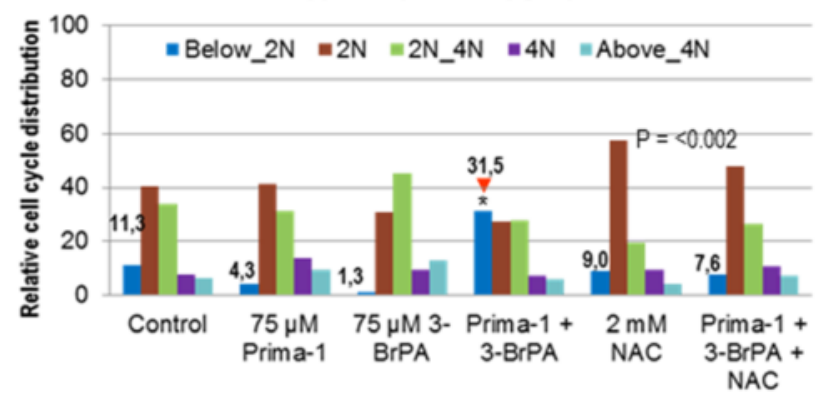

Fig. 3 a NAC counteracts toxicity of Prima-1 and 3-BrPA in hypoxic (G12S)-mutant KRAS-A549 cells. Crystal violet staining of surviving cells was used to compare the response to a $72 \mathrm{~h}$ treatment with Prima-1 or 3-BrPA in A549 cultures under hypoxia in complete Dulbecco's medium containing $20 \mathrm{mM}$ glucose, $4 \mathrm{mM}$ glutamine supplemented with 10\% serum. b and c Prima-1 and 3-BrPA cooperate to inhibit cell cycle progression and promote hypoxic cell death is antagonized by NAC. Cell cycle analysis and assay of below_2n dead cells was performed as indicated under Methods for cells cultured under hypoxia for $48 \mathrm{~h}$ in $20 \mathrm{mM}$ glucose, $4 \mathrm{mM}$ glutamine supplemented with 10\% serum, or $5 \mathrm{mM}$ glucose, $2 \mathrm{mM}$ glutamine and $5 \%$ dialyzed serum. * denotes significance between treated cells relative to controls 
Prima-1 cooperates with 3-BrPA to increase ROS

Since 3-BrPA antagonized p21CDKN1A mRNA induction by Prima-1 (Fig. 1c), and $50 \mu \mathrm{M}$ Prima-1 and $150 \mu \mathrm{M}$ 3-BrPA cooperated to increase A549 cell inhibition (Fig. 1a) this suggested that induction of p21CDKN1A was not the major mechanism involved in the potentiation of toxicity by these agents. Based on reports that single treatment with Prima-1 $[6,8,10-12]$ or with 3-BrPA $[24,25]$ increased ROS production, we investigated whether this effect was additive. For this, ROS production derived from the intracellular esterase processing of the cell-permeant 2',7'-dichlorodihydrofluorescein diacetate (DCFH-DA, Life Technologies, Carlsbad, Ca.) was quantitated cytofluorometrically, by measuring the normalized mean green fluorescence intensity. This showed that ROS production was essentially doubled after a $9 \mathrm{~h}$ treatment with both of these agents, prior to any evidence of overt toxicity which required $48 \mathrm{~h}$ treatments (Fig. 2). Since Prima-1 can alkylate p53 thiol groups [6] and 3-BrPA is another alkylating agent capable of increasing metabolic stress by generating free radicals [24, 25], results in Fig. 2 suggests that potentiation of oxidative stress is likely to mediate the synergy between $50 \mu \mathrm{M}$ Prima-1 and $150 \mu \mathrm{M}$ 3-BrPA, rather than only p53 activation.

\section{NAC counteracts toxicity of Prima-1 and 3-BrPA in (G12S)- mutant KRAS-A549 cells}

Based on the results shown in Fig. 2 we used the antioxidant $\mathrm{N}$-acetylcysteine (NAC) to investigate whether NAC scavenging antagonized the effects of Prima-1 and 3-BrPA. Crystal violet survival studies revealed that Prima-1 was toxic as a single agent after $72 \mathrm{~h}$ of hypoxia against A549 cells in $20 \mathrm{mM}$ glucose $+4 \mathrm{mM}$ glutamine $+10 \%$ serum, which were not affected by 3 -BrPA. However, Prima-1
PRIMA-1 inhibits GLUT1 gene expression in A549 cells

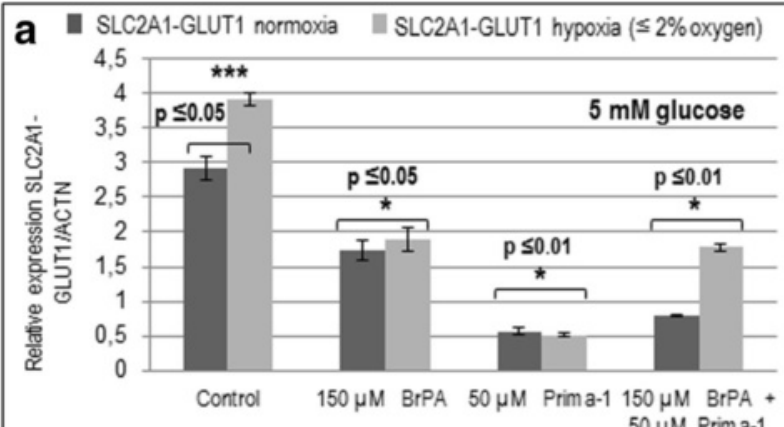

Prima-1 and/or 3-BrPA decrease ALDH1A1 gene expression in A549 cells

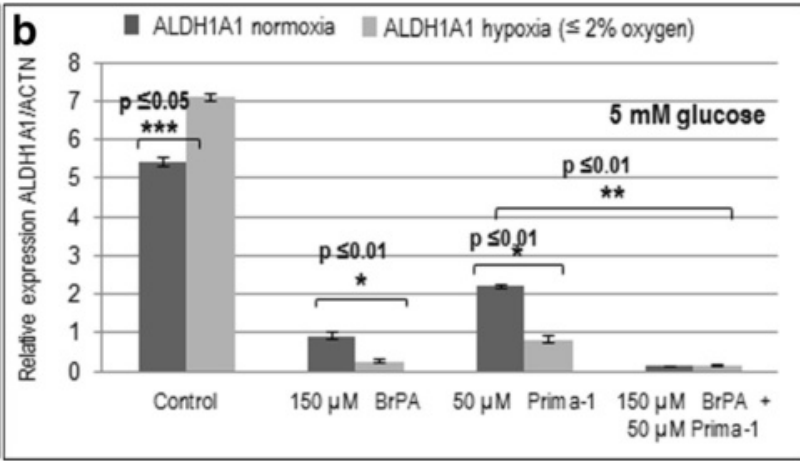

\section{3-BrPA decreases VEGF and CAIX gene expression under hypoxia or normoxia in A549 cells}
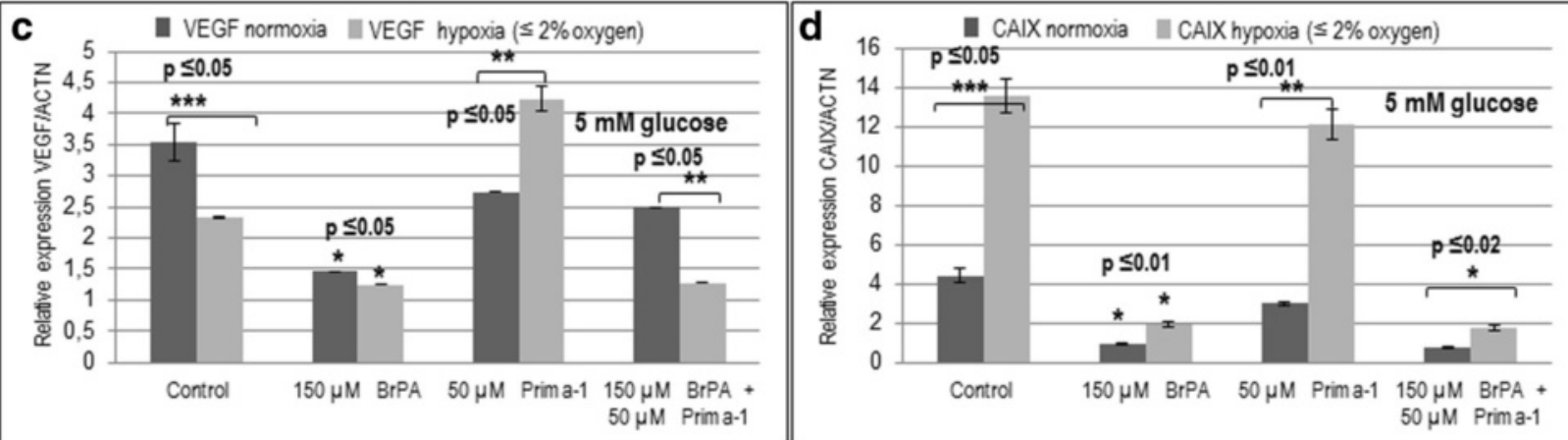

Fig. 4 a Prima-1 lowers SLC2A1-GLUT1 gene expression in $5 \mathrm{mM}$ glucose. A549 cells exposed to $5 \mathrm{mM}$ glucose, $2 \mathrm{mM}$ glutamine and $5 \%$ dialyzed serum, were kept for $4 \mathrm{~h}$ in hypoxia whenever indicated, followed by RNA isolation, and RT-qPCR, to assay SLC2A1-GLUT1 and ACTN gene expression bv qPCR, as indicated under Methods. $\mathbf{b}$ Decrease in ALDH1A1 induced by 3-BrPA is potentiated by Prima-1. Cells treated as indicated above were exposed to hypoxia whenever indicated, followed by RNA isolation, and RT-qPCR, to assay ALDH1A1 and ACTN gene expression bv RT- qPCR. c 3-BrPA counteracts Prima-1 hypoxic induction of VEGF gene expression. Cells treated as indicated above were exposed to hypoxia whenever indicated, followed by RNA isolation, and RT-GPCR, to assay VEGF and ACTN gene expression by RT- GPCR. $\mathbf{d}$ 3-BrPA suppresses CAIX gene expression. Cells seeded as indicated above were exposed to hypoxia for $4 \mathrm{~h}$ whenever indicated, followed by RNA isolation, and RT-qPCR, to assay CAIX and ACTN gene expression by q PCR. * denotes significance between treated cells relative to controls. ${ }^{*}$ denotes significance between unequal treatments. ***denotes significance between hypoxia and normoxia 
toxicity against hypoxic A549 cells was counteracted by NAC even when added together with 3-BrPA (Fig. 3a).

Prima-1 and 3-BrPA cooperation to inhibit cell cycle progression and promote hypoxic $(<2 n)$ cell death is antagonized by NAC

Cell cycle analysis was used to determine the influence of glucose supplementation and the consequences of $48 \mathrm{~h}$ treatments with Prima-1, 3-BrPA or NAC, under hypoxia. In $20 \mathrm{mM}$ glucose and $4 \mathrm{mM}$ glutamine, control cells and those treated with NAC were mostly in S phase $(2 n-4 n)$. Cell cycle progression decreased reciprocally with an augmentation of the below_2n dead cell population [32] with single Prima-1 treatment and even more when this treatment was accompanied by 3-BrPA, effect reverted by NAC (Fig. 3b). In contrast, in $5 \mathrm{mM}$ glucose, $2 \mathrm{mM}$ glutamine and $5 \%$ dialyzed serum, there was an increase in the below_2n dead cell population when both Prima-1 and 3-BrPA were added to hypoxic A549 cells (Fig. 3c).

GLUT1 is preferentially decreased by Prima-1 and ALDH1A1 is decreased by Prima-1 or 3-BrPA in 5 mM glucose in A549 cells

We also investigated the contribution of 3-BrPA to the regulation of GLUT1 and ALDH1A1 in physiological

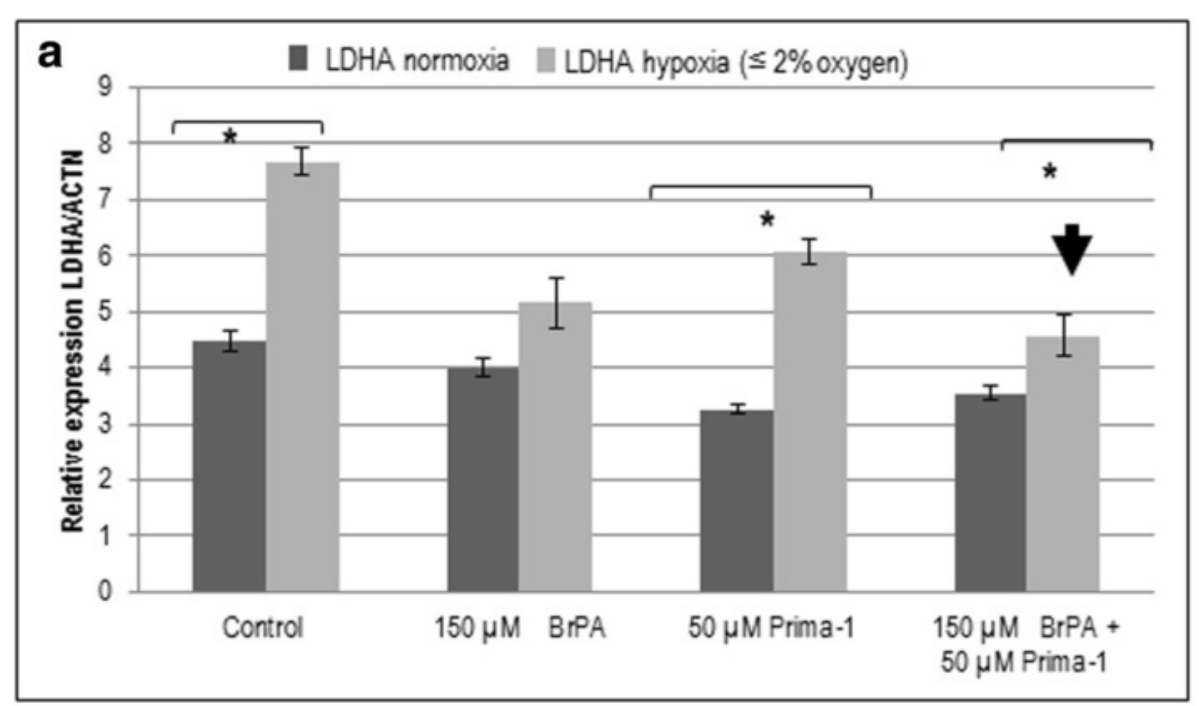

Cells in $5 \mathrm{mM}$ glucose $\pm 3 \mathrm{hr}$ in $21 \%$ oxygen or $\leq 2 \%$ oxygen

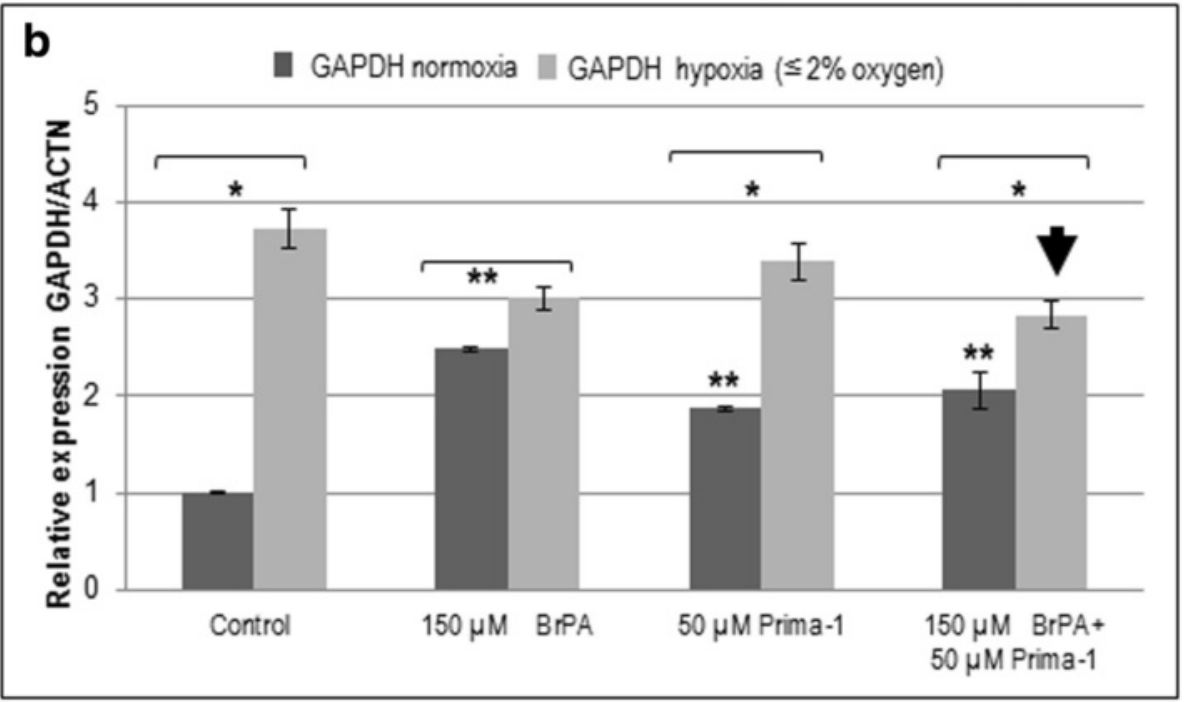

Fig. 5 Prima-1 and 3-BrPA preferentially decrease hypoxia-induced LDHA rather than GAPDH in A549 cells. RT-qPCR was used to assay the effect of 3-BrPA and Prima-1 on LDHA and GAPDH gene expression under normoxia or $3 \mathrm{~h}$ under hypoxia. Note that combined use of Prima-1 and 3-BrPA lowers hypoxic LDHA expression in about $40 \%$, in contrast to only an approximate $25 \%$ decline in hypoxic GAPDH expression by the same combined treatment. ${ }^{*}$ denotes significance between hypoxic and normoxic cells. ${ }^{* *}$ denotes significance between treated and control cells 
$5 \mathrm{mM}$ glucose including Prima-1 when indicated. This revealed the preferential SLC2A1-GLUT1 decrease by Prima-1, partly attenuated by 3-BrPA particularly under hypoxia (Fig. 4a). In contrast, 3-BrPA preferentially down-regulated ALDH1A1 mRNA and this was not attenuated by Prima-1 (Fig. 4b).

Prima-1 mediated enhancement of CAIX and VEGF under hypoxia in $5 \mathrm{mM}$ glucose is antagonized by $3-\mathrm{BrPA}$ in A549 cells

Expression of CAIX and VEGF mRNAs was not lowered significantly by Prima-1, as evidenced by qPCR. However, the expression of these 2 hypoxia-induced genes was diminished by 3-BrPA (Fig. 4c and d).

Prima-1 and 3-BrPA cooperate to preferentially decrease LDHA rather than GAPDH in hypoxic A549 cells in $5 \mathrm{mM}$ glucose

Since LDHA [38] and GAPDH [39] are also involved in glycolysis and hypoxia, their modulation by Prima-1 and/or 3-BrPA was investigated under normoxia or hypoxia in $5 \mathrm{mM}$ glucose. Although mRNA expression of both genes was increased by hypoxia, Prima-1 and 3-BrPA preferentially cooperated to decrease hypoxiainduced LDHA rather than hypoxia-induced GAPDH (Fig. 5a and b).
Prima-1 and 3-BrPA decrease GLUT1 external localization under hypoxia in A549 cells

Since cell-surface localization of the GLUT1 receptor is expected to promote glucose uptake [40], immune fluorescence localization of GLUT1 was compared in hypoxic control cells and in those treated with Prima-1, 3-BrPA, and/or the anti-oxidant $\mathrm{N}$-acetylcysteine NAC, whenever indicated. This revealed preferential surface fluorescence essentially in control cells (Fig. 6).

\section{Hypoxic resistance to 3-BrPA in mutant KRAS C8161 cells} is counteracted by Prima-1

The susceptibility to Prima-1, 3-BrPA and NAC in MelJuso cells (BRAF wild-type (wt) and NRAS-Q61L mutant) [29] was compared with that of C8161 melanoma with an enhancing KRAS G12D mutation and a G464E mutation in the BRAF $P$ loop region [31]. Under normoxia, both cell types were highly suceptible to either $75 \mu \mathrm{M}$ Prima-1 or $100 \mu \mathrm{M}$ 3-BrPA. However, NAC only protected C8161 cells from treatment with Prima-1 and 3-BrPA (Fig. 7a). Under hypoxia, susceptibility to Prima-1 persisted in both cell types but NRAS-mutant MelJuso cells showed greater susceptibility to 3-BrPA, compared to C8161 cells. Another difference between these 2 cell types was that $2 \mathrm{mM}$ NAC counteracted the toxicity of Prima-1 and 3-BrPA only in hypoxic C8161 cells with no comparable attenuation against MelJuso cells (Fig. 7b).

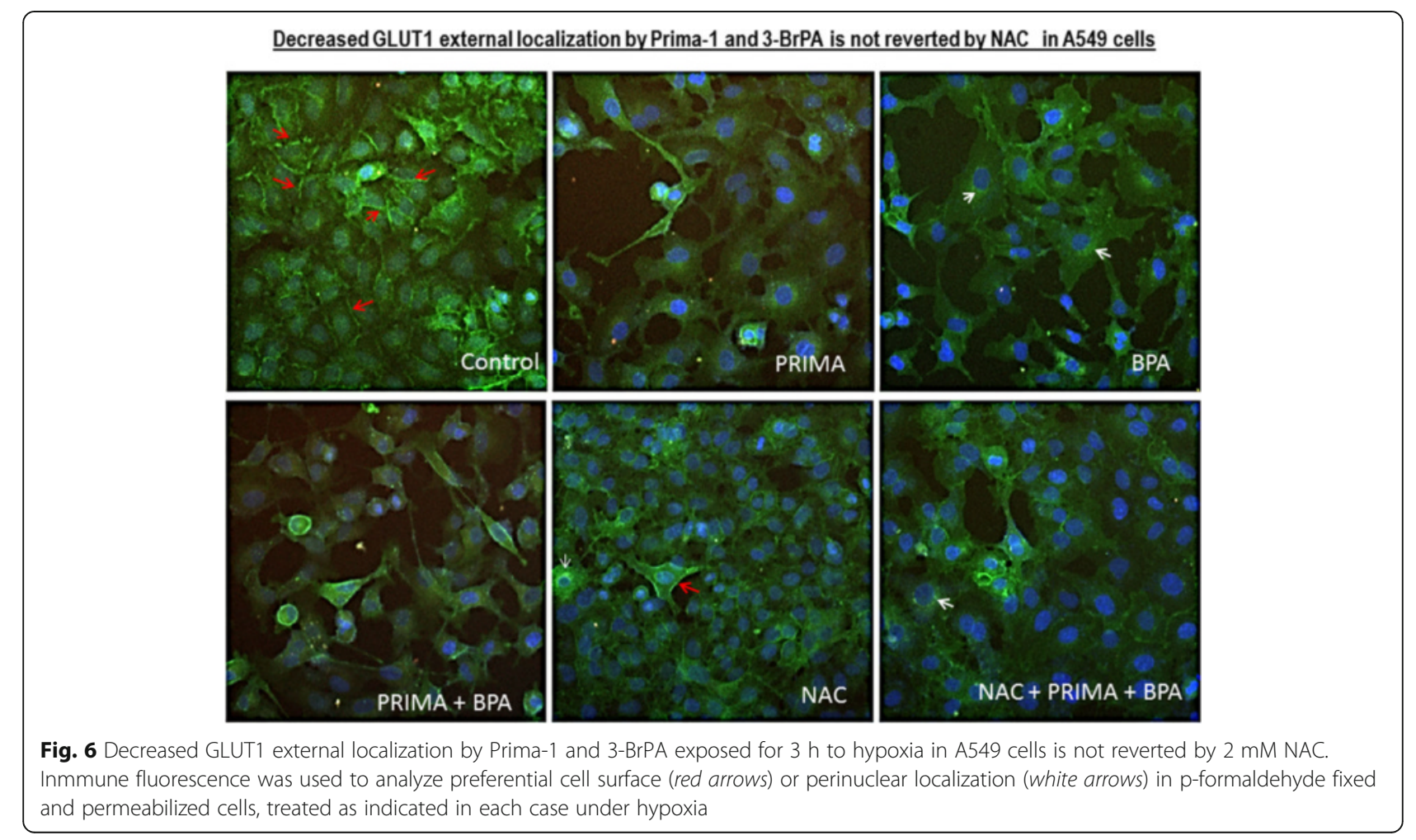




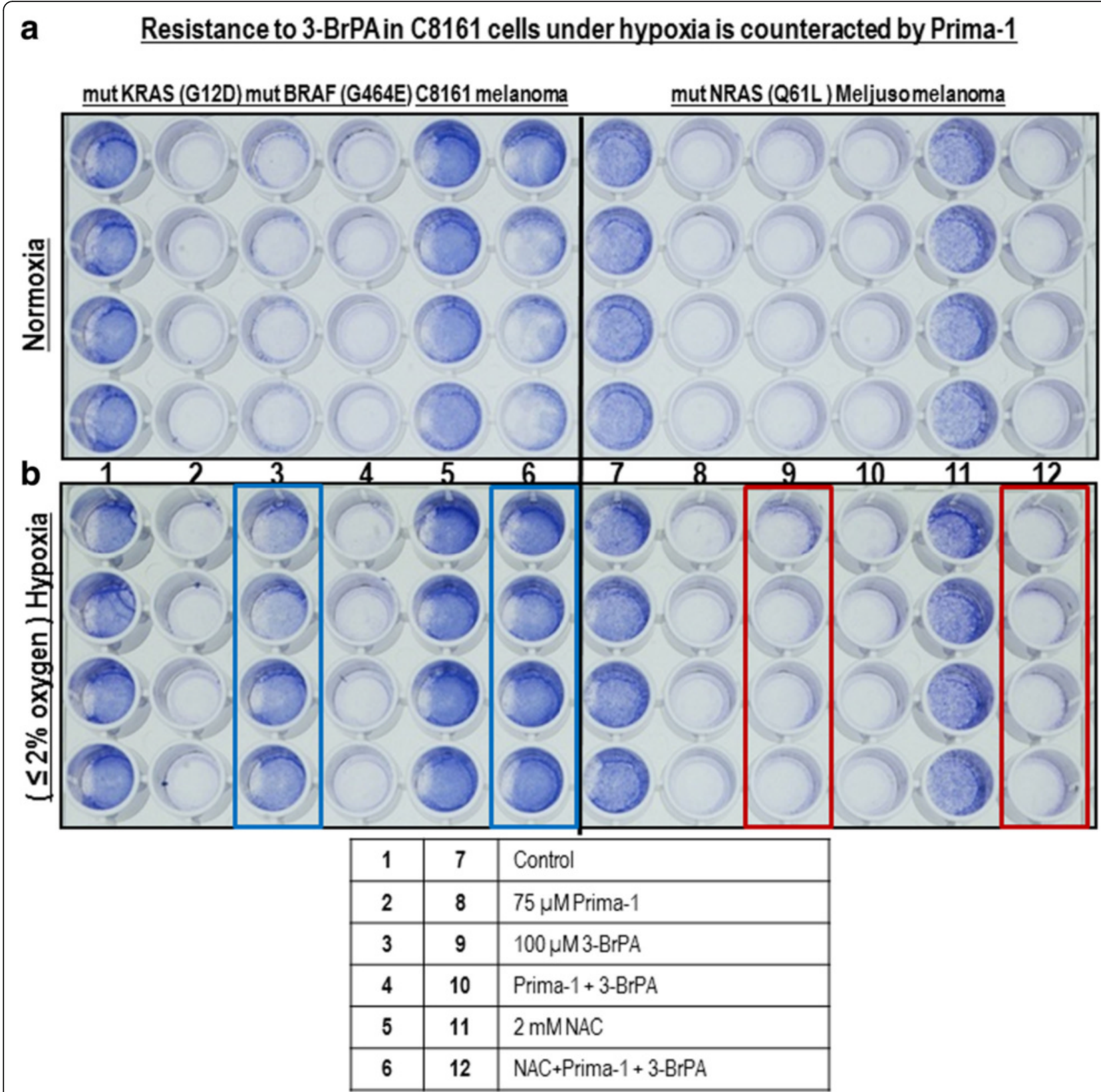

Fig. 7 Resistance to 3-BrPA exposed for $4 \mathrm{~h}$ to hypoxia is counteracted by Prima-1 in C8161 cells. $5 \times 10^{3}$ C8161 and MelJuso cells were allowed to adhere for $18 \mathrm{~h}$ in complete Dulbecco's medium with $20 \mathrm{mM}$ glucose, $4 \mathrm{mM}$ glutamine and 10\% fetal bovine serum, and subsequently exposed to the indicated treatments in the same medium for $72 \mathrm{~h}$, followed by $3 \mathrm{~h}$ of hypoxia or normoxia. After washing twice in phosphate buffered saline $\mathrm{pH} 7.4$, adherent cells were fixed in $70 \%$ ethanol and surviving cells were evidenced by crystal violet staining a) normoxic cells; b) hypoxic cells

The NAC results counteracting the toxicity of Prima-1 and 3-BrPA also imply that this is mediated by oxidative stress, as shown for A549 cells (Figs. 2 and 3).

\section{Unequal modulation of glycolysis-hypoxia associated} gene expression in MelJuso and C8161 cells

Since 3-BrPA decreased VEGF and CAIX and Prima-1 inhibited SLC2A1-GLUT1 gene in KRAS-mutant A549 cells under hypoxia (Fig. 3), these parameters were also investigated by RT-qPCR in MelJuso and C8161 cells. When normalized to actin mRNA levels, control MelJuso cells showed much lower SLC2A1-GLUT1 expression than C8161 cells under comparable conditions. Although 3-BrPA increased the SLC2A1-GLUT1 expression in MelJuso cells, this was attenuated by Prima-1. Neither 3-BrPA nor Prima-1 lowered significantly SLC2A1-GLUT1 expression in C8161 cells under normoxia (not shown). However, SLC2A1-GLUT1 
expression was diminished by $3-\mathrm{BrPA}$, Prima-1 or both treatments after $5 \mathrm{~h}$ of hypoxia in C8161 cells (Fig. 8a, b). Although CAIX gene expression was inhibited by Prima-1 in MelJuso and C8161 cells (Fig. 9a and b), ALDH1A1 and VEGF gene expression were inhibited by Prima-1 only in MelJuso cells (Fig. 9).

\section{Discussion}

3-BrPA is a pro-oxidant and alkylating anti-tumor agent capable of inhibiting glycolytic and mitochondrial targets and generating free radicals [17, 24, 25]. 3-BrPA at $110 \mu \mathrm{M}$ was shown to suppress the growth of colorectal carcinoma cells with KRAS or BRAF mutations surviving glucose starvation [26]. In contrast, we showed in aerobic ER $\alpha$ positive breast cancer cells, that wt p53 conferred resistance to 3-BrPA, since p53 silencing, or use of genetically matched cells with mutant p53 R175H, revealed high susceptibility to $75 \mu \mathrm{M} 3$-BrPA [41]. The wt p53-induced resistance to 3-BrPA was independently confirmed in RT4 (grade I; wild-type p53) bladder cancer cells that remained unaffected by $125 \mu \mathrm{M} 3-\mathrm{BrPA}$, in contrast to T24 (grade III; mutant $p 53$ ) bladder cancer cells, which greatly diminished their survival at comparable 3-BrPA concentrations [42]. This report further investigated how to enhance 3-BrPA toxicity against wt p53 A549 non-small cell lung cancer cells harbouring a KRAS G12S gene mutation. These A549 cells also showed poor susceptibility to 3-BrPA (Figs. 1 and 2). Others previously reported poor susceptibility to

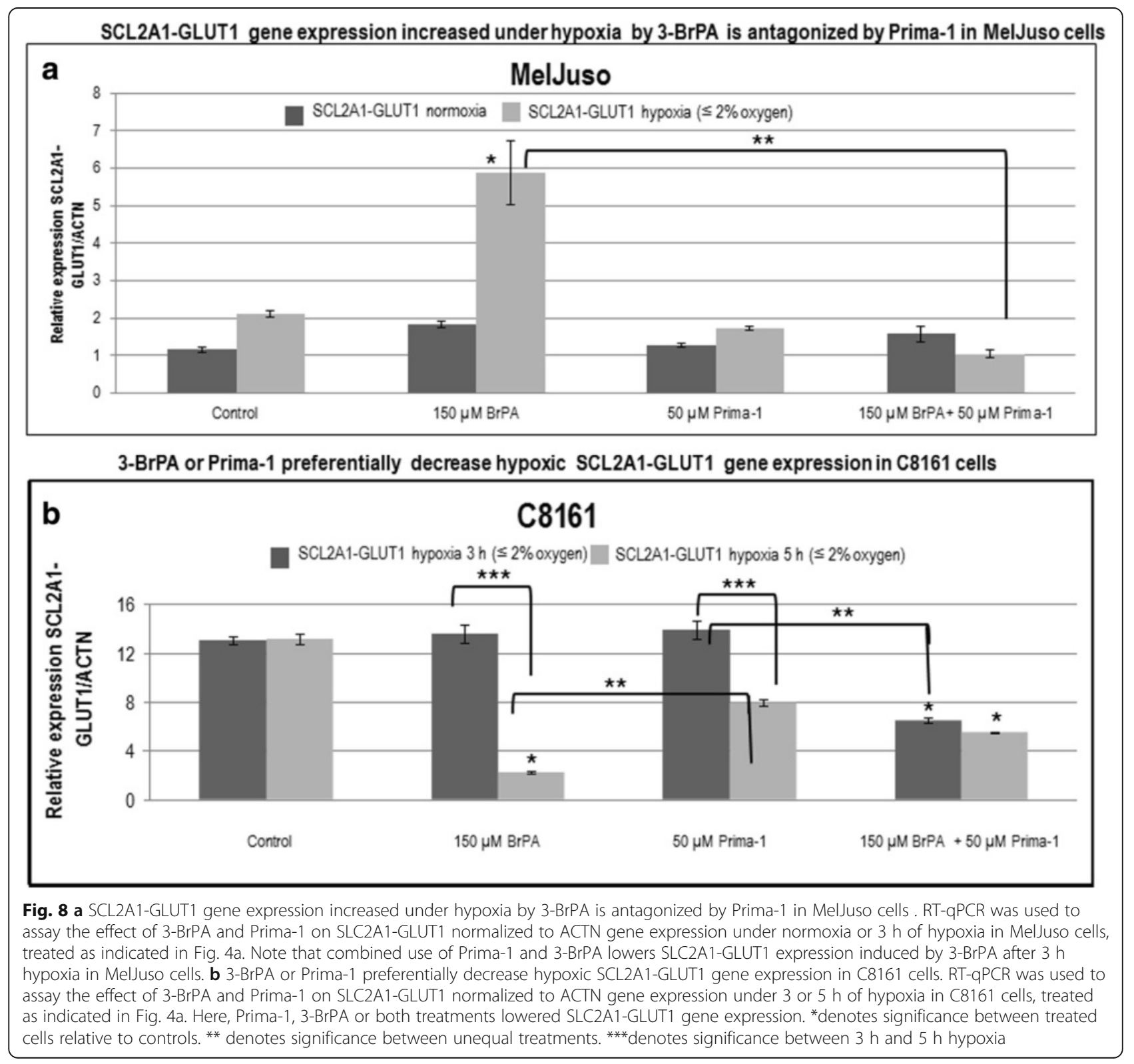




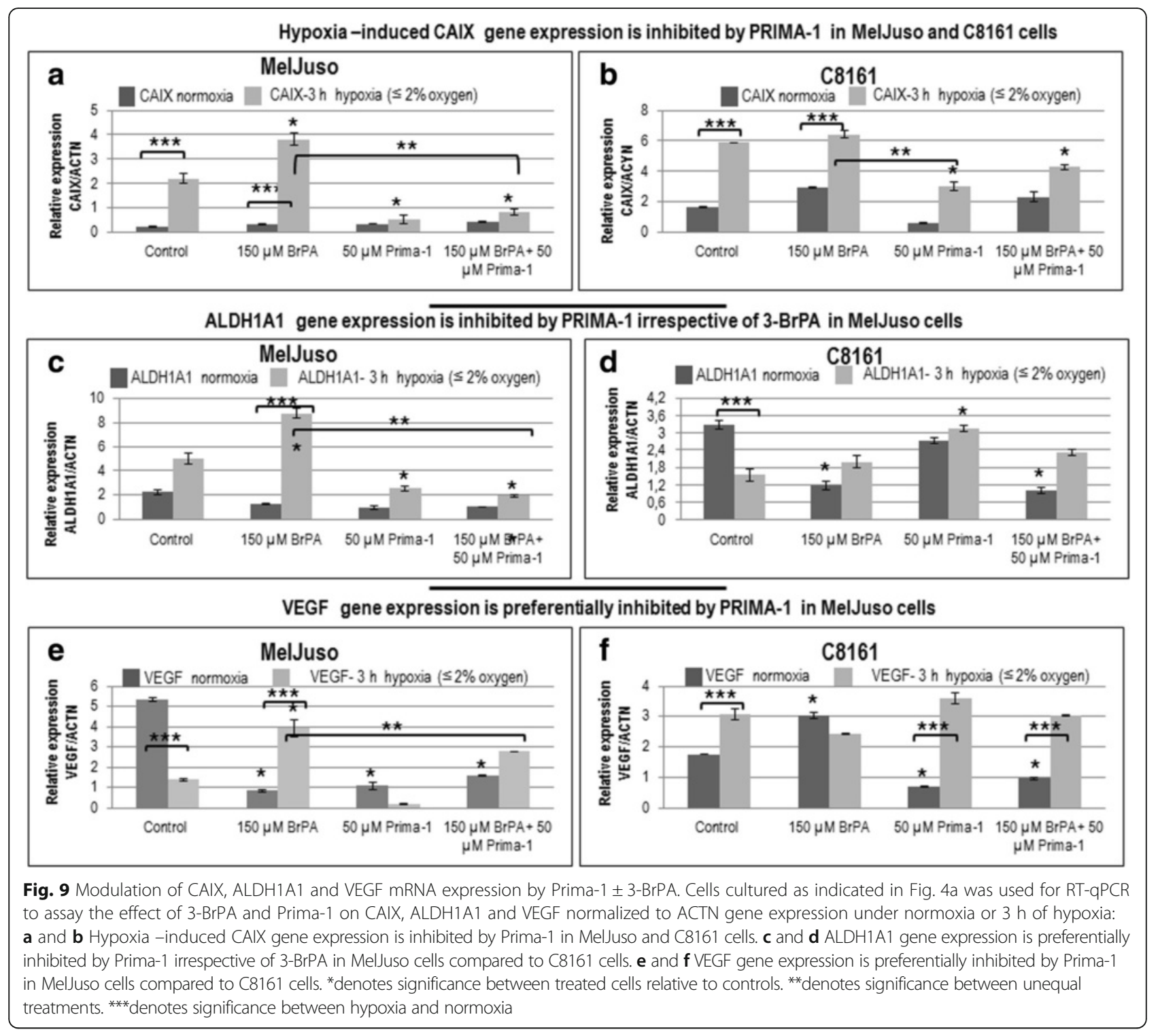

$100 \mu \mathrm{M}$ Prima-1 in aerobic A549 cells in RPMI 1640 medium containing $11 \mathrm{mM}$ glucose plus any sugar contained in non-dialyzed 10\% fetal bovine serum [31]. Since basal oxidative stress is increased by mutant $\mathrm{p} 53$ [13] or mutant KRAS [14], and can be further exacerbated by 3-BrPA [25] or Prima-1 [12], we showed for the first time that the latter 2 agents cooperate to hyperinduce ROS under aerobic conditions (Fig. 2) and counteract hypoxic resistance to 3 -BrPA using physiological $5 \mathrm{mM}$ glucose levels. Although KRAS mutant cells overexpress glucose transporter-1 (SLC2A1-GLUT1) [14] with some of the glucose directed to attenuate excessive oxidative stress through the generation of NADPH by the pentose phosphate pathway [14-16], we showed that Prima-1 decreased GLUT-1 expression in A549 cells (Fig. 1b) and in C8161 cells (Fig. 5c), result compatible with that of other p53-reactivating molecules [43]. Moreover, $50 \mu \mathrm{M}$ Prima-1 also synergized with $150 \mu \mathrm{M}$ 3-BrPA rather than with $150 \mu \mathrm{M} \mathrm{CHC}$ to inhibit A549 aerobic cell proliferation (Fig. 1a). Under hypoxia, A549 cells were also resistant to $150 \mu \mathrm{M} 3$-BrPA but susceptible to $75 \mu \mathrm{M}$ Prima-1, when used as single agents (Fig. 3a). The toxicity caused by Prima-1 + 3-BrPA under hypoxia involved excessive ROS, since it was reversed by the glutathione precursor, NAC (Fig. 3a). The $72 \mathrm{~h}$ crystal violet assay after hypoxic treatment with $75 \mu \mathrm{M}$ Prima-1 (Fig. 3a) is compatible with reports of Prima-1 anti-tumor activity under hypoxia irrespective of p53 status $[8,11]$. A cytofluorometric cell cycle analysis [32] after a shorter $48 \mathrm{~h}$ hypoxic treatment confirmed that Prima-1 was more effective than 3-BrPA as a single agent against KRAS-mutant A549 but also showed that 
3-BrPA cooperated to inhibit cell cycle progression and promote $(<2 \mathrm{n})$ cell death antagonized by NAC in these cells (Fig. $3 \mathrm{~b}$ and $\mathrm{c}$ ). NAC prevented Prima- $1 \pm 3$-BrPA toxicity against hypoxic KRAS G12S-mutant A549 cells (Fig. 3) and KRAS G12D-mutant C8161 cells (Fig. 7). In contrast, hypoxic NRAS-(Q61L)-mutant MelJuso melanoma cells were greatly susceptible to 3-BrPA or Prima-1, but were not protected by NAC (Fig. 7b). Unequal response to NAC may be linked to lower endogenous antioxidant glutathione in hypoxic NRAS-(Q61L)-mutant MelJuso susceptible cells, and lower basal SCL2A1GLUT1 mRNA expression normalized to actin mRNA, compared to that seen in the 3-BrPA resistance in hypoxic C8161 cells (Fig. 8). In our studies, cells were seeded in complete Dulbecco's medium containing $20 \mathrm{mM}$ glucose supplemented with undialyzed $10 \%$ serum for $24 \mathrm{~h}$. followed by washing $3 \mathrm{X}$ with PBS and treated as indicated in each case in medium supplemented with physiological $5 \mathrm{mM}$ glucose and $5 \%$ dialyzed serum. The transition from 20 to $5 \mathrm{mM}$ glucose together with a hypoxic ( $\leq 2 \%$ oxygen) possibly mimicked a restrictive glucose condition [44]. The latter affects inducibility of HIF- $1 \alpha$ and some of the genes induced by hypoxia, which requires not only low oxygen but significant glucose availability [44-47]. This may explain the lower VEGF expression in $5 \mathrm{mM}$ glucose in hypoxic A549 (Fig. 4c) and MelJuso cells (Fig. 9e), resembling results showing lower VEGF-A transcripts in mouse pancreas beta cells after hypoglycemia [48] No comparable decrease was seen in VEGF or CAIX mRNA expression in hypoxic C8161 cells (Fig. 9f), implying that the response to hypoxia in $5 \mathrm{mM}$ glucose may be tumor cell-dependent. A similar glucose concentration also enhanced 3-BrPa-induced cell death in colorectal carcinoma Lovo and HT-29 cells, which was suppressed at $20 \mathrm{mM}$ glucose, concomitantly with down-regulation of the hMCT1 bromopyruvate carrier [44]. Our findings that hypoxia increases resistance to 3-BrPA in KRAS-mutant wt p53 tumor cells rather than in those with NRAS mutation, and the reversal of this resistance with Prima-1 is important, because no effective single clinical therapy has been consistently achieved to treat tumors linked to KRAS [28, 37, 38] or NRAS mutations [28, 40, 49-51]. The greater susceptibility to Prima- \pm 3 -BrPA in hypoxic mutant NRAS MelJuso melanoma (Summary, Fig. 10), suggests that agents like Prima-1 +3-BrPA, may help attenuate the frequent acquisition of resistance to

\section{Summary}

Hypoxic resistance of KRAS mutant cells to 3-BrPA correlates with greater attenuation of Prima-1 toxicity by NAC

\section{mut NRAS (Q61L) \\ MelJuso melanoma}

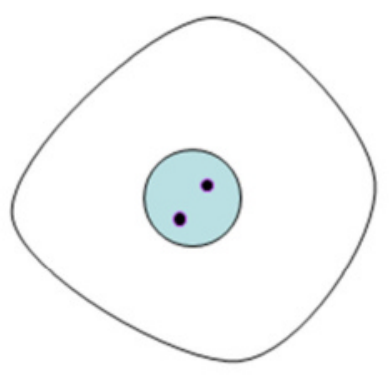

mut KRAS (G12D) mut BRAF (G464E)

\section{C8161 melanoma}

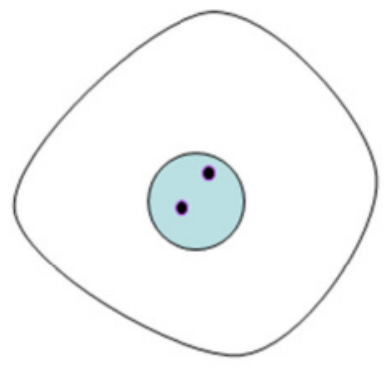

mut KRAS (G12S)

A549 lung carcinoma

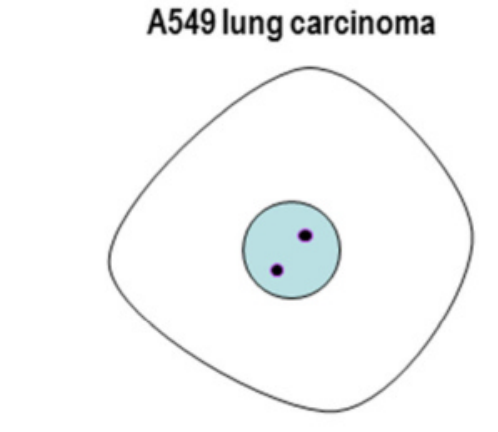

Hypoxic resistance to 3-BrPA and susceptibility to Prima-1, reversed by NAC supplementation

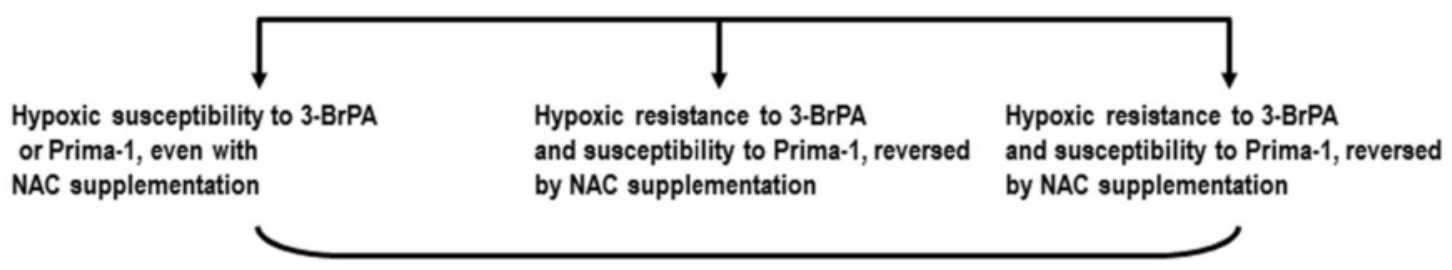

Hypoxic susceptibility to $3 \cdot \mathrm{BrPA}$ or Prima-1, even with NAC supplementation

GLUT1 and ALDH1A1 mRNA expression lowered by Prima-1 1 3-BrPA

Fig. 10 SUMMARY NRAS. NRAS-mutant cell hypoxic susceptibility to Prima-1 \pm 3 -BrPA is not reversed by 2 mM NAC. Hypoxic resistance of KRAS mutant cells to 3-BrPA correlates with greater attenuation of Prima-1 toxicity by 2 mM NAC 
targeted therapy against V600E BRAF-mutated tumors which acquire NRAS mutations [52].

\section{Conclusions}

This report compared tumor cells with KRAS or NRAS mutations, because those with HRAS constitute only 1$3 \%$ of human cancers [53], with KRAS or NRAS mutations being more frequent. Mutated KRAS induces GLUT1 $[26,39]$ and stem cell-like properties in human cancer [54] linked to ALDH1A1 expression [18, 19]. Prima-1 by itself or in combination with 3-BrPA downregulates these genes and also lowers CAIX [20,21] and VEGF mRNA expression [55]. Addressing the question of toxicity of this combination treatment on normal cells, Prima- 1 analog PRIMA-1 ${ }^{\text {Met }}$ shows limited cytotoxicity toward normal hematopoietic cells while decreasing multiple myeloma cell viability irrespective of p53 status [56]. Similarly, 3-BrPA does not affect nonmalignant cells [57] being incorporated into glycolytic tumor cells through the monocarboxylate transporter hMCT1 [58] known to be down-regulated by high glucose [44]. Hence, resistance of hypoxic KRAS-mutant tumor cells to 3-BrPA through lower hMCT1 is likely to be antagonized by lower glucose uptake linked to diminished GLUT-1 transporter expression, a p53 function [59] now shown to be reactivated by Prima-1. Taken together, this is the first report showing that Prima-1 overcomes the resistance to 3-BrPA in hypoxic wt p53 KRAS-mutant cells $[8,28,33,60]$ by promoting wt p53 reactivation [61] and pro-oxidant cancer therapeutics $[9,12,62]$.

\section{Highlights}

- Hypoxia increases resistance to 3-bromopyruvate (3-BrPA) in KRAS-mutant wt p53 cells

- Prima-1, a p53 reactivator decreases GLUT1 and counteracts hypoxic resistance to 3-BrPA

- $\mathrm{N}$-acetylcysteine reverts toxicity induced by Prima-1 and 3-BrPA

\section{Abbreviations}

3-BrPA: 3-bromopyruvate; CAIX: Carbonic anhydrase 9; ROS: Reactive oxygen species; SLC2A1-GLUT1: Glucose transporter 1; VEGF: Vascular endothelial growth factor

\section{Acknowledgements}

The financial support by Fonacit-Misión Ciencia subproyecto SPNS 4-Cancer to Manuel Rieber is gratefully appreciated.

\section{Funding}

This research project was supported by Fonacit-Misión Ciencia subproyecto SPNS 4-Cancer to Manuel Rieber. Funders and sponsors had no role in the study design, in the collection, analysis and interpretation of data; in the writing of the manuscript; and in the decision to submit the manuscript for publication.

\section{Availability of data and material}

The dataset supporting the conclusions of this article is available on request.

\section{Authors' contributions}

Conceived and designed the study: MR and MSR; Performed cell culture and laboratory analysis: VC, AO, and MSR; Performed RT-qPCR analysis: AO; Performed immune blots MSR; Performed cell cycle and immune fluorescence: VC; Wrote and revised the manuscript: MR and MSR. All authors read and approved the final manuscript.

\section{Competing interests}

The authors declare that they have no competing interests.

\section{Consent for publication}

Not applicable.

\section{Ethics approval and consent to participate}

Since no clinical samples were used, ethical approval and consent were not deemed necessary by the Ethics Committee.

Received: 18 March 2016 Accepted: 26 October 2016

Published online: 18 November 2016

\section{References}

1. Lee SH, Shen GN, Jung YS, Lee SJ, Chung JY, Kim HS, Xu Y, Choi Y, Lee JW, Ha NC, Song GY, Park BJ. Antitumor effect of novel small chemical inhibitors of Snail-p53 binding in K-Ras-mutated cancer cells. Oncogene. 2010;29(32): 4576-87.

2. Licciulli S, Avila JL, Hanlon L, Troutman S, Cesaroni M, Kota S, Keith B, Simon MC, Puré E, Radtke F, Capobianco AJ, Kissil JL. Notch1 is required for Krasinduced lung adenocarcinoma and controls tumor cell survival via p53. Cancer Res. 2013;73:5974-84

3. Tecleab A, Zhang X, Sebti SM. Ral GTPase down regulation stabilizes and reactivates p53 to inhibit malignant transformation. J Biol Chem. 2014;289: 31296-309.

4. Bykov VJ, Issaeva N, Shilov A, Hultcrantz M, Pugacheva E, Chumakov P.

5. Bergman J, Wiman KG, Selivanova G. Restoration of the tumor suppressor function to mutant p53 by a low-molecular-weight compound. Nat Med. 2002;8:282-8.

6. Nahi H, Lehmann S, Mollgard L, Bengtzen S, Selivanova G, Wiman KG, et al. Effects of PRIMA-1 on chronic lymphocytic leukaemia cells with and without hemizygous p53 deletion. Br J Haematol. 2004;127:285-91.

7. Lambert JM, Gorzov P, Veprintsev DB, Söderqvist M, Segerbäck D, Bergman J, Fersht AR, Hainaut P, Wiman KG, Bykov VJ. PRIMA-1 reactivates mutant p53 by covalent binding to the core domain. Cancer Cell. 2009;15:376-88.

8. Bao W, Chen M, Zhao X, Kumar R, Spinnler C, Thullberg, Issaeva N, Selivanova G, Strömblad S. PRIMA-1Met/APR-246 induces wild-type p53dependent suppression of malignant melanoma tumor growth in 3D culture and in vivo. Cell Cycle. 2011;10:301-7.

9. Rieber, M. Strasberg-Rieber, M. Hypoxia, Mn-SOD and $\mathrm{H}_{2} \mathrm{O}_{2}$ regulate $\mathrm{p} 53$ reactivation and PRIMA-1 toxicity irrespective of p53 status in human breast cancer cells. Biochem Pharmacol; 2012: 1563-1570

10. Tessoulin B, Descamps G, Moreau P, Maïga S, Lodé L, Godon C, MarionneauLambot S, Oullier T, Le Gouill S, Amiot M, Pellat-Deceunynck C. PRIMA-1 Met induces myeloma cell death independent of p53 by impairing the GSH/ROS balance. Blood. 2014;124:1626-36.

11. Aryee DN, Niedan S, Ban J, Schwentner R, Muehlbacher K, Kauer M, Kofler R, Kovar $\mathrm{H}$. Variability in functional p53 reactivation by PRIMA-1(Met)/APR-246 in Ewing sarcoma. Br J Cancer. 2013:109(10):2696-704.

12. Supiot S, Zhao H, Wiman K, Hill RP, Bristow RG. PRIMA-1 (met) radiosensitizes prostate cancer cells independent of their MT p53-status. Radiother Oncol. 2008:86:407-11

13. Peng X, Zhang MQ, Conserva F, Hosny G, Selivanova G, Bykov VJ, Arnér ES, Wiman KG. APR-246/PRIMA-1MET inhibits thioredoxin reductase 1 and converts the enzyme to a dedicated NADPH oxidase. Cell Death Dis. 2013;4: e881.

14. Kalo E, Kogan-Sakin I, Solomon H, Bar-Nathan E, Shay M, Shetzer Y, Dekel E, Goldfinger N, Buganim Y, Stambolsky P, Goldstein I, Madar S, Rotter V. Mutant p53R273H attenuates the expression of phase 2 detoxifying enzymes and promotes the survival of cells with high levels of reactive oxygen species. J Cell Sci. 2012;125(Pt 22):5578-86. 
15. Du J, Tsao MS, Oberley LW, Cullen JJ. K-ras oncogene increases reactive oxygen species (ROS): Mechanisms involved in regulating pancreatic cancer cell growth. Free Radic Biol Med. 2007;43:S53.

16. Sasaki H, Shitara M, Yokota K, Hikosaka Y, Moriyama S, Yano M, Fujii Y. Overexpression of GLUT1 correlates with Kras mutations in lung carcinomas. Mol Med Rep. 2012;5:599-602.

17. Andrisse S, Koehler RM, Chen JE, Patel GD, Vallurupalli VR, Ratliff BA, Warren DE, Fisher JS. Role of GLUT1 in regulation of reactive oxygen species. Redox Biol. 2014;2:764-71.

18. Chavez-Perez VA, Strasberg-Rieber M, Rieber M. Metabolic utilization of exogenous pyruvate by mutant p53 (R175H) human melanoma cells promotes survival under glucose depletion. Cancer Biol Ther. 2011;12:647-56.

19. Shien K, Toyooka S, Yamamoto H, Soh J, Jida M, Thu KL, Hashida S, Maki Y, Ichihara E, Asano H, Tsukuda K, Takigawa N, Kiura K, Gazdar AF, Lam WL, Miyoshi S. Acquired resistance to EGFR inhibitors is associated with a manifestation of stem cell-like properties in cancer cells. Cancer Res. 2013;73:3051-61.

20. Alamgeer M, Ganju V, Szczepny A, Russell PA, Prodanovic Z, Kumar B, Wainer Z, Brown T, Schneider-Kolsky M, Conron M, Wright G, Watkins DN. The prognostic significance of aldehyde dehydrogenase $1 \mathrm{~A} 1$ (ALDH1A1) and CD133 expression in early stage non-small cell lung cancer. Thorax. 2013;68:1095-10.

21. Tafreshi NK, Lloyd MC, Bui MM, Gillies RJ, Morse DL. Carbonic anhydrase IX as an imaging and therapeutic target for tumors and metastases. Subcell Biochem. 2014;75:221-54.

22. Ilie M, Hofman V, Zangari J, Chiche J, Mouroux J, Mazure NM, Pouysségur J, Brest $\mathrm{P}$, Hofman P. Response of CAIX and CAXII to in vitro re-oxygenation and clinical significance of the combined expression in NSCLC patients. Lung Cancer. 2013;82:16-23.

23. Ilie M, Mazure NM, Hofman V, Ammadi RE, Ortholan C, Bonnetaud C, Havet K, Venissac N, Mograbi B, Mouroux J, Pouysségur J, Hofman P. High levels of carbonic anhydrase IX in tumour tissue and plasma are biomarkers of poor prognostic in patients with non-small cell lung cancer. Br J Cancer. 2010; 102:1627-35.

24. Wassman CD, Baronio R, Demir Ö, Wallentine BD, Chen CK, Hall LV, Salehi F, Lin DW, Chung BP, Hatfield GW, Richard Chamberlin A, Luecke H, Lathrop $\mathrm{RH}$, Kaiser $\mathrm{P}$, Amaro RE. Computational identification of a transiently open L1/S3 pocket for reactivation of mutant p53. Nat Commun. 2013:4:1407.

25. Glick M, Biddle P, Jantzi J, Weaver S, Schirch D. The antitumor agent 3bromopyruvate has a short half-life at physiological conditions. Biochem Biophys Res Commun. 2014;452:170-3.

26. Zhang Q, Zhang Y, Zhang P, Chao Z, Xia F, Jiang C, Zhang X, Jiang Z, Liu H. Hexokinase II inhibitor, 3-BrPA induced autophagy by stimulating ROS formation in human breast cancer cells. Genes Cancer. 2014;5:100-12.

27. Chen G, Xu X, Zhang L, Fu Y, Wang M, Gu H, Xie X. Blocking autocrine VEGF signaling by sunitinib, an anti-cancer drug, promotes embryonic stem cell self-renewal and somatic cell reprogramming. Cell Res. 2014;24:1121-36.

28. Yun J, Rago C, Cheong I, Pagliarini R, Angenendt P, Rajagopalan H, Schmidt K, Willson JK, Markowitz S, Zhou S, Diaz Jr LA, Velculescu VE, Lengauer C, Kinzler KW, Vogelstein B, Papadopoulos N. Glucose deprivation contributes to the development of KRAS pathway mutations in tumor cells. Science. 2009:325:1555-9.

29. Samatar AA, Poulikakos PI. Targeting RAS-ERK signalling in cancer: promises and challenges. Nat Rev Drug Discov. 2014;13:928-42.

30. Smalley KS, Haass NK, Brafford PA, Lioni M, Flaherty KT, Herlyn M. Multiple signaling pathways must be targeted to overcome drug resistance in cell lines derived from melanoma metastases. Mol Cancer Ther. 2006;5:1136-44.

31. Yu X, Ambrosini G, Roszik J, Eterovic AK, Stempke-Hale K, Seftor EA, Chattopadhyay C, Grimm E, Carvajal RD, Hendrix MJ, Hodi FS, Schwartz GK, Woodman SE. Genetic Analysis of the 'Uveal Melanoma' C918 Cell Line Reveals Atypical BRAF and Common KRAS Mutations and Single Tandem Repeat Profile Identical to the Cutaneous Melanoma C8161 Cell Line. Pigment Cell Melanoma Res. 2015;28:357-9.

32. Liang SX, Richardson DR. The effect of potent iron chelators on the regulation of p53: examination of the expression, localization and DNAbinding activity of p53 and the transactivation of WAF1. Carcinogenesis. 2003;24:1601-14.

33. Ideno M, Sasaki S, Kobayashi M, Futagi Y, Narumi K, Iseki K. Influence of high glucose state on bromopyruvate-induced cytotoxity by human colon cancer cell lines. Drug Metab Pharmacokinet. 2016;31:67-72.

34. Duan W, Gao L, Wu X, Wang L, Nana-Sinkam SP, Otterson GA, Villalona-Calero MA. MicroRNA-34a is an important component of PRIMA-1-induced apoptotic network in human lung cancer cells. Int J Cancer. 2010;127:313-20.
35. Hamdan L, Arrar Z, Al Muataz Y, Suleiman L, Négrier C, Mulengi JK, Boukerche H. Alpha cyano-4-hydroxy-3-methoxycinnamic acid inhibits proliferation and induces apoptosis in human breast cancer cells. PLoS One. 2013:8:e72953.

36. Le NT, Richardson DR. Potent iron chelators increase the mRNA levels of the universal cyclin-dependent kinase inhibitor p21(CIP1/WAF1), but paradoxically inhibit its translation: a potential mechanism of cell cycle dysregulation. Carcinogenesis. 2003;24:1045-58.

37. Sugai T, Habano W, Jiao YF, Suzuki M, Takagane A, Nakamura S. Analysis of genetic alterations associated with DNA diploidy, aneuploidy and multiploidy in gastric cancers. Oncology. 2005;68:548-57.

38. Liu XH, Zheng XF, Wang YL. Inhibitive effect of 3-bromopyruvic acid on human breast cancer MCF-7 cells involves cell cycle arrest and apoptotic induction. Chin Med J (Engl). 2009;122:1681-5.

39. Le A, Cooper CR, Gouw AM, Dinavahi R, Maitra A, Deck LM, Royer RE, Vander Jagt DL, Semenza GL, Dang CV. Inhibition of lactate dehydrogenase A induces oxidative stress and inhibits tumor progression. Proc Natl Acad Sci U S A. 2010;107:2037-42.

40. Krasnov GS, Dmitriev AA, Snezhkina AV, Kudryavtseva AV. Deregulation of glycolysis in cancer: glyceraldehyde-3-phosphate dehydrogenase as a therapeutic target. Expert Opin Ther Targets. 2013;17:681-93.

41. Rieber M, Strasberg-Rieber M. p53 inactivation decreases dependence on estrogen/ERK signalling for proliferation but promotes EMT and susceptility to 3-bromopyruvate in ERa+ breast cancer MCF-7 cells. Biochem Pharmacol. 2014;88:169-77.

42. Konstantakou EG, Voutsinas GE, Velentzas AD, Basogianni AS, Paronis E, Balafas E, Kostomitsopoulos N, Syrigos KN, Anastasiadou E, Stravopodis DJ. 3-BrPA eliminates human bladder cancer cells with highly oncogenic signatures via engagement of specific death programs and perturbation of multiple signaling and metabolic determinants. Mol Cancer. 2015;14:135.

43. Zawacka-Pankau J, Grinkevich W, Hünten S, Nikulenkov F, Gluch A, Li H, Enge M, Kel A, Selivanova G. Inhibition of glycolytic enzymes mediated by pharmacologically activated p53: targeting Warburg effect to fight cancer. J Biol Chem. 2011;286:41600-15.

44. Pan Y, Oprysko PR, Asham AM, Koch CJ, Simon MC. p53 cannot be induced by hypoxia alone but responds to the hypoxic microenvironment. Oncogene. 2004;23:4975-83.

45. Liu Z, Jia X, Duan Y, Xiao H, Sundqvist KG, Permert J, Wang F. Excess glucose induces hypoxia-inducible factor-1a in pancreatic cancer cells and stimulates glucose metabolism and cell migration. Cancer Biol Ther. 2013; 14:428-35.

46. Kwon SJ, Lee YJ. Effect of low glutamine/glucose on hypoxia-induced elevation of hypoxia-inducible factor-1alpha in human pancreatic cancer MiaPaCa-2 and human prostatic cancer DU-145 cells. Clin Cancer Res. 2005; 11:4694-700.

47. Guo S, Bragina $O, X u$ Y, Cao Z, Chen H, Zhou B, Morgan M, Lin Y, Jiang BH, Liu KJ, Shi H. Glucose up-regulates HIF-1 alpha expression in primary cortical neurons in response to hypoxia through maintaining cellular redox status. J Neurochem. 2008;105:1849-60.

48. Xiao X, Guo P, Chen Z, El-Gohary Y, Wiersch J, Gaffar I, Prasadan K, Shiota C, Gittes K. Hypoglycemia reduces vascular endothelial growth factor A production by pancreatic beta cells as regulator of beta cell mass. J Biol Chem. 2013;288:8636.

49. Kelleher FC, McArthur GA. Targeting NRAS in melanoma. Cancer J. 2012;18:132-6.

50. Mandalà M, Merelli B, Massi D. Nras in melanoma: targeting the undruggable target. Crit Rev Oncol Hematol. 2014;92:107-22.

51. Dovey M, White RM, Zon LI. Oncogenic NRAS cooperates with p53 loss to generate melanoma in zebrafish. Zebrafish. 2009;6:397-404.

52. Lidsky M, Antoun G, Speicher P, Adams B, Turley R, Augustine C, Tyler D, AliOsman F. Mitogen-activated protein kinase (MAPK) hyperactivation and enhanced NRAS expression drive acquired vemurafenib resistance in V600E BRAF melanoma cells. J Biol Chem. 2014;289:27714-26.

53. Prior IA, Lewis PD, Mattos C. A comprehensive survey of Ras mutations in cancer. Cancer Res. 2012;72:2457-67.

54. Gierut JJ, Lyons J, Shah MS, Genetti C, Breault DT, Haigis KM. Oncogenic KRas promotes proliferation in quiescent intestinal stem cells. Stem Cell Res. 2015;15:165-71.

55. Xu J, Wang J, Xu B, Ge H, Zhou X, Fang JY. Colorectal cancer cells refractory to anti-VEGF treatment are vulnerable to glycolytic blockade due to persistent impairment of mitochondria. Mol Cancer Ther. 2013;12:717-24. 
56. Saha MN, Jiang H, Yang Y, Reece D, Chang H. PRIMA-1Met/APR-246 displays high antitumor activity in multiple myeloma by induction of p73 and Noxa. Mol Cancer Ther. 2013;12:2331-41.

57. Isayev O, Rausch V, Bauer N, Liu L, Fan P, Zhang Y, Gladkich J, Nwaeburu CC, Mattern J, Mollenhauer M, Rückert F, Zach S, Haberkorn U, Gross W, Schönsiegel F, Bazhin AV, Herr I. Inhibition of glucose turnover by 3bromopyruvate counteracts pancreatic cancer stem cell features and sensitizes cells to gemcitabine. Oncotarget. 2014;5:5177-89.

58. Birsoy K, Wang T, Possemato R, Yilmaz OH, Koch CE, Chen WW, Hutchins AW, Gultekin Y, Peterson TR, Carette JE, Brummelkamp TR, Clish CB, Sabatini DM. MCT1-mediated transport of a toxic molecule is an effective strategy for targeting glycolytic tumors. Nat Genet. 2013;45:104-8.

59. Schwartzenberg-Bar-Yoseph F, Armoni M, Karnieli E. The tumor suppressor p53 down-regulates glucose transporters GLUT1 and GLUT4 gene expression. Cancer Res. 2004;64:2627-33.

60. Yang L, Zhou Y, Li Y, Zhou J, Wu Y, Cui Y, Yang G, Hong Y. Mutations of p53 and KRAS activate NF-KB to promote chemoresistance and tumorigenesis via dysregulation of cell cycle and suppression of apoptosis in lung cancer cells. Cancer Lett. 2015;357:520-6.

61. Aloni-Grinstein R, Shetzer Y, Kaufman T, Rotter V. p53: the barrier to cancer stem cell formation. FEBS Lett. 2014;588(16):2580-9.

62. Wondrak GT. Redox-Directed Cancer Therapeutics: Molecular Mechanisms and Opportunities. Antioxid Redox Signal. 2009;1 1:3013-69.

\section{Submit your next manuscript to BioMed Central and we will help you at every step:}

- We accept pre-submission inquiries

- Our selector tool helps you to find the most relevant journal

- We provide round the clock customer support

- Convenient online submission

- Thorough peer review

- Inclusion in PubMed and all major indexing services

- Maximum visibility for your research

Submit your manuscript at www.biomedcentral.com/submit

) Biomed Central 